\title{
Motivated monitoring: the importance of the institutional investment horizon
}

\section{Article}

\section{Accepted Version}

Creative Commons: Attribution-Noncommercial-No Derivative Works 4.0

Yin, C., Ward, C. and Tsolacos, S. (2018) Motivated monitoring: the importance of the institutional investment horizon. International Review of Financial Analysis, 60. pp. 197-212. ISSN 1057-5219 doi: https://doi.org/10.1016/j.irfa.2018.08.011 Available at https://centaur.reading.ac.uk/78924/

It is advisable to refer to the publisher's version if you intend to cite from the work. See Guidance on citing.

To link to this article DOI: http://dx.doi.org/10.1016/j.irfa.2018.08.011

Publisher: Elsevier

All outputs in CentAUR are protected by Intellectual Property Rights law, including copyright law. Copyright and IPR is retained by the creators or other copyright holders. Terms and conditions for use of this material are defined in the End User Agreement.

\section{www.reading.ac.uk/centaur}

\section{CentAUR}

Central Archive at the University of Reading 
Reading's research outputs online 
Accepted Manuscript

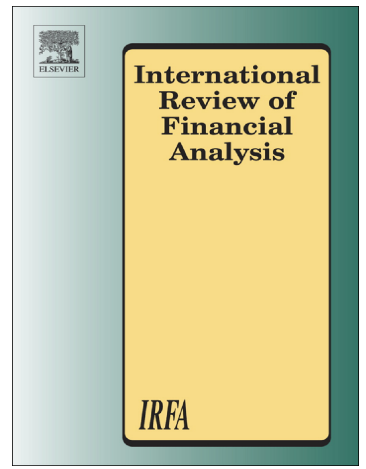

Chao Yin, Charles Ward, Sotiris Tsolacos

PII: $\quad$ S1057-5219(18)30423-X

DOI: $\quad$ doi:10.1016/j.irfa.2018.08.011

Reference: $\quad$ FINANA 1247

To appear in: $\quad$ International Review of Financial Analysis

Received date: $\quad 6$ June 2017

Revised date: $\quad 7$ August 2018

Accepted date: $\quad 23$ August 2018

Please cite this article as: Chao Yin, Charles Ward, Sotiris Tsolacos , Motivated monitoring: The importance of the institutional investment horizon. Finana (2018), doi:10.1016/j.irfa.2018.08.011

This is a PDF file of an unedited manuscript that has been accepted for publication. As a service to our customers we are providing this early version of the manuscript. The manuscript will undergo copyediting, typesetting, and review of the resulting proof before it is published in its final form. Please note that during the production process errors may be discovered which could affect the content, and all legal disclaimers that apply to the journal pertain. 


\title{
Motivated monitoring: the importance of the institutional investment horizon ${ }^{1}$
}

\author{
Chao Yin* \\ ICMA Centre, Henley Business School, University of Reading
}

Charles Ward

ICMA Centre, Henley Business School, University of Reading

Sotiris Tsolacos

Cass Business School, City University

$29 / 07 / 2018$

*Contact information of corresponding author:

Dr. Chao Yin

Lecturer in Finance, ICMA Centre, Henley Business School

University of Reading,

Whiteknights, Shinfield Road,

Reading, UK

RG6 6BA

Email: chao.yin@icmacentre.ac.uk

\footnotetext{
${ }^{1}$ We are grateful for comments from Seth Armitage, Lynn Hodgkinson, Chris Brooks and the referee.
} 


\title{
Motivated monitoring: the importance of the institutional investment horizon
}

\begin{abstract}
This paper investigates whether institutional investors that hold shares in a firm for a relatively long time affect firm performance. We measure performance by Return on Assets (ROA), Tobin's Q and Earnings Yield and find that long-term ownership has a positive, long-lasting effect on firm performance. We minimize concerns about endogeneity by incorporating random shocks from changes in the constituents of the Russell Index. We further find that the incentive for monitoring firm performance associated with long-term holding is more important than some conventional classifications of investors in improving firm value. Even for investors usually classified as short term, firm performance will be enhanced for those firms in which they hold stocks over longer periods. We also find that a positive link between institutional owners and firm performance does not exist when investors only hold the stock for a short term. Overall, our paper supports the argument that institutional investors' monitoring enhances firm value.
\end{abstract}




\section{Introduction}

The influence of institutional investors on the firm has been studied extensively and investor heterogeneity has been shown to be associated with a range of governance outcomes. Investor characteristics such as turnover, portfolio concentration, fiduciary duty, investment style and business links with firms are emphasized in the literature because these are believed to indicate different incentives among investors to monitor firms (Gaspar et al. 2005; Neubaum and Zahra 2006; Chen et al. 2007; Yan and Zhang 2009; Elyasiani and Jia 2010; Attig et al. 2012; Aghion et al. 2013; Cella et al. 2013). Overall, investors who are long-term orientated and more independent are typically believed to be more effective monitors and to play a more positive role in firm governance and value.

However, although it could be agreed that different institutional investors might behave differently, little has been discovered on whether each institution would play a similar role in its different holding firm. An institution's role in corporate governance could be largely different among its holding firms, for two reasons. First of all, institutional investors are complex entities providing different investment products. A large institutional investor, such as Black Rock, with $\$ 5.1$ trillion assets under management, ${ }^{2}$ could manage more than 20 different funds following different investment styles and trading strategies. The assumption that it will maintain equal monitoring across all its holdings is simplistic and has been rejected by recent empirical evidence (Armitage et al. 2017). Secondly, monitoring resources are limited (Sims 2003; Kacperczyk et al. 2016). On average, institutional investors hold more than 200 stocks in their portfolio (Ward et al. 2018). Therefore, they are unlikely to devote an equal amount of time monitoring every firm in which they hold stock. As noted by Fich et al. (2015) and Ward et al. (2018), institutions' monitoring incentives and resource allocation vary substantially across their portfolio. Consistent

${ }^{2}$ The data is estimated at December 312016 and disclosed at https://www.blackrock.com/au/individual/aboutblackrock. 
with this view, an emerging literature is looking at institutional investors' monitoring and resource allocation.

This paper examines a specific dimension of institutional characteristics: the investment horizon. Investment horizons matter because shareholder activism and monitoring activities are costly and challenging to implement and require a sufficiently long period to realize benefits (Chen et al. 2007). Investment horizons will reflect the investors' choice between short-term transactions and longer-term commitments to the firm being held, hence long-term institutional ownership may be an important factor in determining firm policies and operational efficiency by the firms in which institutions have invested.

The majority of previous studies have looked at investment horizons on an investor level. They classify investors as long- or short-term investors based on the firm's turnover. (Yan and Zhang 2009; Cella et al. 2013; Chichernea et al. 2015). This approach assumes that investors would consistently be a long- or short-term investors in all their holding companies and overlooks the holding horizon difference caused by business complexity and resource limitation. To account for this difference, compared with the traditional literature we classify investment horizons with respect to each stock held within the institutional investors' portfolios. When an institutional investor holds stocks in a specific firm for more than three years, it is considered as a long-term investor for this specific firm. We find that institutional investors' holding horizons may vary more substantially than previously assumed. On average, we find that shor-term investors (using the turnover based definition) typically hold more than a quarter of the stocks in their portfolios for more than three years. As a corollary, within the portfolios of investors traditionally classified as being long term, less than $50 \%$ of the stocks in firms are held for more than three years. These statistics show that although institutions may be classified as long- or short-term investors, they can hold portfolios of stocks that do not uniformly fit into these categorizations. Taking these within-portfolio variations into account, we re-examine the question: does a higher 
monitoring incentive, measured by the length of institutions' holdings in a firm, enhance firm value? The simple answer is "yes". We find that an increase in the long-term holdings of institutional investors is associated with higher subsequent return on assets, Tobin's ratio and earnings yield. This is a persistent effect which lasts for at least five years and is consistent for all three performance measures used.

A potential interpretation of our results is that since our measure of incentive variation is positively correlated with the range of different institutional investors, our result may simply reflect the different types of investors. For example, the effect on firm performance that we ascribe to an increase in long-term holdings by all investors could more simply be ascribed to an increase in the type of investor previously classified as being long term. In other words, we need to distinguish between the effect of investor type and the behavior of investors in general. To clarify this issue, we look at the long-term holdings of each type of investor, under three different classification schemes. We find that higher long-term holding of all types of investor is consistently associated with superior firm performance in the future. Even for transient investors whose investment horizon overall is short (Chen et al. 2007) and "grey investors", such as banks and insurance companies, whose monitoring capability might be compromised by their business links with the firm (Ferreira and Matos 2008; Chung et al. 2012; Luong et al. 2016), their longterm holdings are still found to be value enhancing. These consistent findings indicate that the monitoring effect that stems from variation within investors' portfolios is clearly distinct from changes in the types of institution.

To address any concerns of endogeneity about whether firms will hold firms with better performance for longer periods, following the recent literature we use an instrumental variable approach by exploiting exogenous shocks on the long-term ownership generated by changes in the composition of the Russell indices ( Fich et al. 2015; Appel et al. 2016; Schmidt and Fahlenbrach 2016). When firms are included or excluded from the Russell 1000 and Russell 
2000 index due to relative market capitalization changes, the change in the weight of a firm in the index will drive index tracker funds to rebalance their portfolio and lead to associated trading by other institutions. Therefore, after controlling for market capitalization, the shock provides a clear method of identifying the effect of long-term holdings on firm performance free from endogeneity concerns (Fich et al. 2015). All our estimates are valid under this 2SLS framework. Moreover, to avoid the concern that our results may be subject to the idiosyncratic choice of variable, we use alternative measures to test the robustness of the approach; our results and conclusions remain valid.

A related issue is whether the short-term holdings of institutional investors have the same effect on firm performance. Studies such as Aghion et al. (2013) and Giannetti and Yu (2018), find that short-term holdings can also lead to better firm operations because they can readily exercise their power by selling their holdings, whereas other studies conclude that short-term investors' holdings can have a negative effect on subsequent performance (Gaspar et al. 2005; Chichernea et al. 2015). Thus, the story as to whether short-term holdings influence future performance is somewhat ambiguous. By applying the same analytical framework, the short-term holdings of institutional investors are defined as shares with less than one year overall holding length. We find that firm performance is reduced following an increase in institutional investors' short -term holding. These findings imply that even if institutions have the capability to undertake firm monitoring, the lack of incentive arising from their short-term perspective will fail to increase performance.

In summary, in line with previous studies such as Gaspar et al. (2005) and Chichernea et al. (2015), we conclude that the institutional monitoring incentive, as measured by its holding horizon, tends to be positively related to firm performance. These findings support the argument that investor monitoring creates value. This assessment also accords with recent evidence, such 
as Fich et al. (2015), that investors will distribute their attention allocation unevenly and tilt the monitoring resource to a subset of firms held in their portfolios.

Our findings contribute to two strands of the literature. First, they provide new evidence that institutional shareholders will increase firm value. There is an ongoing debate on the overall effect of institutional monitoring of the firm. Some studies argue that strong shareholders willing to intervene would lead to worse operational outcome because the active institutional investor might exploit the private benefits of control or might increase managerial myopia (La Porta et al. 1999; Cronqvist and Fahlenbrach 2009; Cai et al. 2016). Other studies hold the opposing view and emphasize the benefits of institutional monitoring and engagement with a consequent reduction in agency costs (Chen et al. 2007; Fich et al. 2015). Our study provides evidence that the benefit of shareholder monitoring clearly outweighs the cost of monopolistic shareholder power.

In addition, this study also relates to the literature which discusses the effect of heterogeneity between institutions based on firm outcomes (Appel et al. 2016; Schmidt and Fahlenbrach 2016). We conclude that the incentive variation within an institutional portfolio has an independent and stronger effect on firm performance than changes in the distribution of different types of institutional investor, in accordance to the argument of Fich et al. (2015) .

The rest of the paper is organized as following: Section 2 will be a literature review and hypothesis development. This is followed by a description of our data source and variable construction (Section 3). The main empirical test will be discussed in Section 4 and this is followed by reports on the endogeneity and robustness tests (Sections 5 and 6) before the conclusion in Section 7. 


\section{Key hypothesis and related litereture}

Previous studies argue that institutional investors may exert influence on a firm through two mechanisms. The first is the 'voice' that represents the direct intervention of the investor in corporate activities. For example, McCahery, Sautner, and Starks (2016) surveyed institutional investors and investigated how they engage with firms. They found that the most frequently used intervention methods, in decreasing order of frequency, are: (1) voting against management at the annual general meeting, (2) initiating discussion with the executive board, (3) contacting the supervisory board, (4) disclosing their voting against management, and (5) publicly criticising executive board members. Their study provides direct evidence of institutional investors' intervention in corporate governance. There are also many studies documenting the effects of institutional intervention on the firm. These studies frequently use shareholder activism to represent the intervention of shareholders through the voice channel. For example, Bradley et al. (2010) found that institutional investors could force the closed-end funds to be open-ended, thereby creating value by eliminating the closed-end fund discount. Brav et al. (2008) applied an event-study framework and found that shareholder activism leads to an average $7 \%$ abnormal return around the announcement date. They also found evidence that such events lead to improvements in the pay-out ratio, return on assets, and operating margins. Brav, Jiang, \& Kim (2015) used plant-level data and found that shareholder intervention leads to improved productivity, especially in business strategy-orientated interventions.

Recent studies have begun to investigate the second mechanism through which institutional investors may monitor firm operations and reduce agency problems - trading firms' shares. This effect is frequently referred to as the 'exit' channel. If a manager does not behave in a manner that improves shareholder value, investors may sell their shareholdings. This selling would lead to a decrease in the share price and punish the irresponsible behaviour of management ex post. 
The possibility that shareholders may walk away also creates an ex-ante threat that compels managers to act in a way that would fulfill their fiduciary duty (Edmans 2014).

The cost and benefit of institutional monitoring through both "voice" and "exit" channel are closely related to the investment horizon. Chen, Harford, and Li (2007) argue that longer holding horizon could enable institutional investors to acquire a better knowledge of the firm, thereby reducing the cost of monitoring. On the other hand, by holding shares for a long time, institutional investors could exert more influence on the firm through their interaction with the management. Therefore, long time holding could result in greater monitoring benefit. The effectiveness of monitoring through "exit" is also associated with the investment horizon. The event that an institutional investor sells shares of a firm it held for a long period of time will send a much stronger signal to the market than the event that the investor sells a short-term holding firm. Therefore, by holding for a longer period, the threat of exit will become more considerable to management, and the monitoring will become more effective. Because a longer investment horizon will be associated with lower monitoring costs, higher monitoring benefits and more effective exit threats. We should expect a positive relationship between long-term holdings of institutional investors and the performance of the firm.

\section{Data and variable definition}

\subsection{Data source}

Our main source for the accounting data and financial ratios is COMPUSTAT. Ownership data are provided by the Thomson Financial Ownership Database, which reports all holdings of US institutional investors having more than $\$ 100$ million assets under management. To avoid potential problems of mis-identification, recycled and unreliable classifications, we update the 
$13 \mathrm{~F}$ data by using the information provided by Bushee. ${ }^{3}$ Data related to stock prices, returns and trading volume are downloaded from CRSP.

\subsection{Variables definition}

\section{Firm performance measures}

We use three different measurements as proxies for firm performance. The first is Return on Assets (ROA), defined as net income divided by firm asset value. It is a direct measurement of how much net income is generated by a firm per unit of assets. Higher ROAs signal more efficient earnings generation and therefore better performance. The second measure is Tobin's $Q$ ratio $(T B Q)$, the market value of a firm's assets divided by the book value. ${ }^{4}$ Tobin's $Q$ reflects the market view of how valuable a firm's current assets are. When a firm has high growth prospects, Tobin's Q will have a higher value. The third ratio used is the firm's Earnings Yield or Earnings price ratio (EY), which is defined as the prospective earnings per share divided by the current stock price. We use Earnings Yield to measure firms' earning growth, instead of the earnings per share growth rate, to avoid the measurement problem of negative earnings. ${ }^{5}$ When the earnings yield is higher, the firm is valued as having good earnings capacity.

Although in all our regression specifications we controlled for industry fixed effects, the time varying industry characteristic could still influence our results. To minimize such concerns, we adjust the three performance measures by deducting the industry median value from the calculated figure. In non-tabulated results, our findings remain essentially similar if we use unadjusted firm performance measures.

\footnotetext{
${ }^{3}$ Bushee's website, http://acct.wharton.upenn.edu/faculty/bushee/IIclass.html.

${ }^{4}$ Calculated by dividing the sum of market value of equity, long-term debt and debt in current liabilities by the book value.

${ }^{5}$ When the earnings per share (EPS) of the firm in the previous year is negative, a more negative EPS in the current year will lead to a positive EPS growth rate, which is clearly misleading.
} 
Another point worth noting is that all our performance variables are measured as future performance, and current performance is added as a control. There are two reasons for us to apply the model in this way. First, using future performance could partially alleviate the reverse causality concern, because future performance is less likely to be the reason for current ownership variation. Second, for institutional investors to exert their influence on the firm, there will always be a process of information collection. The interaction between shareholders and managers will also take time. Therefore, the effect of institutional holding on firm performance could be delayed.

\section{Long-term institutional ownership.}

We classify institutional ownership into long-term and short-term categories based on the actual holding horizon of each institution in each firm. In our main specification, all institutional ownership lasting for more than three years is classified as long-term ownership. To mitigate the classification error which may be induced by long-term investors' market timing activity, if an investor exits the firm but returns within the following year, its holding period is deemed as continued since the previous period in which it sold its shares. However, if the investor leaves the firm for more than one year, we will reset it's holding period count to 0 when it returns. We then aggregate the ownership of long-term investors at the firm level to create variable of longterm ownership (L3).

Our classification method differs from the one frequently used in the literature. Much of the existing literature classifies investors as long term or short term based on a measure of how quickly they turn over their aggregate portfolio. When portfolio turnover is relatively fast, investors are identified as short-term investors. In contrast, when investors have a relatively low turnover, they are classified as long-term investors. The measurement used is normally the "churn ratio" (Gaspar and Massa 2005, 2006; Yan and Zhang 2009; Attig et al. 2012, 2013; Cella et al. 2013; Chichernea et al. 2015) . 
The "churn ratio", or turnover-based investor classification scheme, assumes that investors maintain the same attitude, preference and behavior regardless of the firms in which they invest. For two reasons, this assumption could be too strong. First of all, in reality institutional investors do not have the same incentives and motivations for all the firms in which they invest. (Fich et al. 2015). The assumption that an investor will treat all the firms held equally is too strong to be realistic. The second reason that the aggregate churn ratio may be misleading is that because of the limitations of the $13 \mathrm{~F}$ holding report, portfolio turnover is reported at the company or institutional level rather than at the fund level. ${ }^{6}$ As a result, a single institution may have several different constituent investing entities that follow different strategies and styles and this will make the churn ratio based classification unreliable. We will provide quantitative estimates of the potential mis-classification problem in Section 4.1.

Our classification of ownership is free of look-ahead bias. Institutional investors are only classified as long-term owners after we observe actual investment horizons longer than three years. For example, if an investor A holds a firm B from December 2005 to December 2008, its holding is classified as long-term holding only in 2008 when we observe its holding is actually long term. This definition may under-estimate the actual long-term holding of the firm since some investors may intend to take a long-term position but actually sell their holdings in a firm after only a short period. Additionally, to avoid the concern of using expost information to form a current variable, we decide not to impute the holding behavior of long-term investors in their first three years of holding stock. In the tabulated results, we also have alternative long-term ownership variables which classify the holdings of the same investor in the first three years also as long-term holding (in our example, holdings of B by A from December 2005 to December 2008). All our test results remain robust.

\section{Control variables}

\footnotetext{
${ }^{6}$ See the Securities and Exchange Commission (SEC) website: ttps://www.sec.gov/answers/form13f.htm.
} 
We also control for other firm characteristics that could distort the findings. To account for firm financing and investment levels, we control for leverage (debt to asset ratio, DTA) and capital expenditure ratio (CAPX). To control the fact that firm might be in different stages of their life cycle, we control for firm size (natural log of market capitalization, LOGMV) and firm age (AGE). Lastly, to control for the liquidity environment that firms might be facing, we control for turnover (TOV) in our regressions. Detailed variable definitions can be found in Appendix A. We also tried specifications with additional control variables such as book to market ratio, stock returns and dividend yield. All our results remained qualitatively similar. However, to avoid concerns of potential multicollinearity, we delete these variables in the final specifications. 


\section{Empirical results: institutional investment horizon and firm performance}

\subsection{Summary statistics}

Who are the long-term investors? Horizon preferences of different types of investors

Before we get to the main analysis of the regression results, we summarize the investment horizon preferences of different investors. We use the three-classification scheme provided by Bushee (2001) to categorize different institutional investors. The first classification is based on institutional portfolio diversification and turnover. Investors who holds more concentrated portfolios with low turnover are classified as dedicated investors and are normally believed to be investors most likely to be engaged in corporate governance (Chen et al. 2007). Investors with more diversified portfolios and lower turnover are classified as quasi-indexers, and investors who have high portfolio turnover and diversified portfolio are classified as transient investors. The second classification is based on the investors' investment styles. Investors who prefer high (low) dividend yield, low (high) market to book ratio and low (high) price to earnings ratio are classified as value (growth) investors while all other investors are classified as growth-income investors on the basis that they do not show clear preferences. (Bushee 2001). The final classification scheme is based on institutional investors' fiduciary duties. The Thomson Financial $13 \mathrm{~F}$ database classifies inyestors into seven categories reflecting their fiduciary responsibilities. These categories comprise Public Pension Funds, Banks, Insurance, Corporate (Private) Pension Funds, University and Foundation Endowment, Investment Companies and Independent Investment Advisors.

reports the institutional preferences in terms of holding horizons. The Average Holdings column shows the percentage of total shares outstanding held by each type of institutional investor. The Average Long-Term Holdings column shows the percentage of total shares outstanding held by investors for more than three years. The Proportion of Long-Term Holdings column shows the 
proportion of each type of institutional investor holdings that are classified as long term. It can be seen from Table 1 that transient investors, growth investors, independent investment advisors and corporate pension funds have the lowest proportions of shares held for more than three years (proportion of long-term holdings ranging from about $25 \%$ to $40 \%$ ). In other words, these investors tend to have shorter horizons. On the other hand, quasi-indexers and value growth investors, banks, investment companies, insurance companies and public pension funds tend to have more long-term holdings in their portfolio (the proportion of their long-term holdings range from about $45 \%$ to $58 \%$ ).

\section{[Table 1]}

Although institutional investors of different kinds show variation in their preferences for longterm holdings, the difference may not be as high as might have been expected. For example, in the dedicated-quasi-indexer-transient scheme, dedicated investors, who might have been expected to be long-term monitoring investors (Chen et al. 2007), hold less than half of their stocks for more than three years while transient investors, who would normally be expected to have the least incentive to take long-term positions, still hold more than a quarter of their portfolios in the long term. These findings show that the within-portfolio variation of institutional investor are substantial and should not be ignored.

\section{Descriptive statistics}

Table 2 reports descriptive statistics for the variables used in our main analysis. As can be seen, long-term ownership in our definition on average accounts for $15 \%$ of firms' shares outstanding as well as accounting for about a half of total institutional ownership. After adjusting for industry effects in the dependent variables, the average and median of all three performance measures are close to 0 . We also note that on average about half of the institutional holdings are long term, showing that long-term ownership is important in terms of shareholder control. 
4.2. Baseline regression: long-term holdings and firm performance

The key research question we investigate is whether a higher level of long-term ownership, and therefore a greater incentive to monitor, is associated with superior firm performance. We adopt the following baseline model:

$$
\text { Performance }_{i, t+1, t+4}=\alpha_{i}+\beta L 3_{i, t}+B * \text { Control Variables } s_{i, t}+\theta_{i}+\mu_{t}+\epsilon_{i, t}
$$

where firm performance measures = industry adjusted Returns on Assets (ROA), Tobin's Q (TBQ) and Earnings Yield (EY).

All performance measures are quarterly averages from quarter $\mathrm{t}+1$ to quarter $\mathrm{t}+4$. Long-term ownership (L3), is defined as the proportion of institutional investors who hold the firm stocks for more than three years. Control variables include leverage (DTA), capital expenditure ratio (CAPX), firm size (LOGMV) and firm age (AGE). We also control for the SIC 2-digit industry $\left(\theta_{i}\right)$ and quarterly time $\left(\mu_{t}\right)$ fixed effects. Our standard errors are clustered at the firm level.

[Table 2]

As can be seen in Table 3, long-term ownership is positively and significantly related to all three measures of firm performance. These results suggest that long-term holdings by institutional investors increase firm values. These findings are consistent with the literature which argues that long-term institutional ownership might improve firm governance and increase firm value (Chen et al. 2007), and they support our claim that institutional investors' monitoring will lead to better firm performance.

[Table 3] 


\subsection{Long-term ownership and long-run performance}

We extend our analysis to longer horizons by looking at the persistence of the influence of longterm ownership on firm value. To do this, we estimate the regression on different subsequent time horizons:

$$
\text { Performance }_{i, t+4 * N}=\alpha_{i}+\beta L 3_{i, t}+B * \text { Control Variables } s_{i, t}+\theta_{i}+\mu_{t}+\epsilon_{i, t}
$$

where the $\mathrm{N}$ in the subscript takes values from 1 to 5 . For each performance measure, we estimate the model by using the performance measure at quarter $t+4 \mathrm{~N}$ for six different time periods.

Over the three performance measures, we have 18 different regressions. Figure 1 shows the estimation of $\beta$ and corresponding confidence interval at the $95 \%$ level.

As can be seen in Figure 1, in all 18 regressions, long-term ownership is always positively related to firm performance and the coefficients are all significant at the $1 \%$ level. Moreover, there is even a rising trend in the coefficients' estimates. These findings clearly show that the value enhancing effect of long-term ownership are persistent.

[Figure 1]

There are two reasons that the long-term holdings of institutional investors could lead to a longlasting effect on the improvement of firm performance. First, the long holdings of institutional investors tend to stay for a long time. ${ }^{7}$ We rank firms according to the long-term holdings of institutional investors into five quantiles and look at the change in their rank 5 years' later. Table B2 in Appendix B reports the result. For a firm with highest long-term institutional holding rank, the chance of still having a high long-term holding rank (4 and 5) after five years is as high as $77.3 \%(19.7 \%+57.6 \%)$. This finding shows that long-term holding of institutional investors are

\footnotetext{
${ }^{7}$ We thank the referee for pointing this out.
} 
long-lasting. Second, the cost of institutional monitoring tends to reduce over time while the benefit tends to increase over time. When investors hold shares for longer period of time, they will have a better existing knowledge of the firm and will be able to process the new information faster. Long-term holdings also enable institutional investors to impose influence on the management, share more financial gain and obtain an information advantage. (Chen, Harford and Li 2007). The long-lasting nature of long-term holding and better cost-benefit trade-off jointly lead to a persistent improvement in firm performance.

\section{Endogeneity and 2SLS regressions}

There is a natural concern that our results might arise through an endogeneity problem. In contrast to the interpretation that monitoring investors improve firm value, it is also possible that investors tend to hold firms which they believe could continue to outperform. In other words, the longer holding length could be the result instead of the reason for higher long-term ownership, thereby giving rise to a reverse causality interpretation. In addition, there may be some factors which influence both the ownership and firm performance for which we failed to control. This would lead to the "omitted variable bias".

Our main analysis does not ignore such concerns. First, our results show that the positive impact of ownership on performance will last for long periods of time. The reverse causality problem will be less likely to be a concern when our dependent variables are much later in time than the independent variable. Second, the industry, year fixed effects and industry adjustment on the dependent variables would be expected to eliminate a large part of any potential omitted variable concerns. Nevertheless, we admit that even with these measures, the endogeneity concern cannot be fully eliminated.

We adopt an IV approach which has been widely used in the literature to address the endogeneity issue. Our identification strategy follows Fich et al. (2015), Crane et al. (2016) and 
Schmidt and Fahlenbrach (2016) which exploit ownership changes caused by the annual changes in the Russell index. The Russell 1000 and 2000 index are reconstituted in June every year. All stocks traded in major US stock markets are ranked by their market capitalization on May 31 each year. The largest 1000 firms are included in the Russell 1000 index, the next 2000 firms are assigned to the Russell 2000 index. Firms that are close to the index threshold are very similar on all aspects (Fich et al. 2015; Appel et al. 2016; Schmidt and Fahlenbrach 2016). As pointed out by Fich et al. (2015), since the Russell indexes are value weighted, the only factor that leads to an index switch is the market capitalization of the firm. As the index switch events are correlated with the market cap, this event is not purely random. Nevertheless, as long as the market capitalization is controlled for in the regression, the index membership change will become random and therefore the exclusion condition is satisfied.

Firms at the bottom of Russell 1000 and Russell 2000 with be allocated a very small weight in the index portfolio. In contrast, the stocks at the top of the Russell 2000 will be given a higher weight. The difference in weight on both sides of the threshold will lead investors who track the Russell 1000 or 2000 index to rebalance their portfolios as a result of the index reconstitution, which will lead to variations in the institutional ownership of the firm. The threshold between the bottom of the Russell 2000 and smaller stocks below will lead to similar variations.

There are several reasons for long-term institutional holdings to be influenced by the index switch. First, passive investors by definition track the index construction, and their holdings are thus influenced by the index switch. Existing studies have found evidence that index tracking investors are effective monitors of the firm. For these investors, selecting a better stock may not be an option. But they can monitor the holding firms to make sure that the firms they have to hold perform better. In addition, passive investors are also entitled to vote. Since on average, they have lower turnover compared to active investors, managers would incline more to their 
views (Appel, et al. 2016). Any index switch would have a significant impact on their ownership and therefore on the effectiveness of monitoring .

Second, the index switch can also influence active investors. Even if active investors are not mimicking the portfolio weight of the index, many of them still need to compare their investment performance with certain benchmarks. For two firms with the same expected future return, active investors would still prefer the one in index membership because to choose this firm could reduce the tracking error of the investment (Wurgler 2010). On the other hand, a firm being added to or deleted from an index are events that attract investor attention. These events may increase the chance that firms become targets of active investors, therefore providing an incentive for active investors to adjust their portfolio.

Based on the rationale above, we adopt a IV regression framework to overcome the endogeneity problem. We use 2SLS approach to estimate the following model:

$$
\begin{gathered}
L 3_{t, i}=\alpha+\beta_{1} R 1 T R 2_{i, t}+\beta_{2} R 2 T R 1_{i, t}+\beta_{3} R 2 T N_{i, t}+\beta_{4} N T R 2_{i, t}+B * \text { Control }_{i, t}+\theta_{i}+\mu_{t} \\
+\epsilon_{i, t}
\end{gathered}
$$

where R1TR2 (R2TR1) are dummy variables taking one in the year following a stock moving from one Russell index to another. R2TN is a dummy variable taking one in the year that the firm dropped out of the Russell index due to a relative fall in market capitalization. NTR2 is a dummy variable taking one in the year the firm is moved from below into the Russell 2000 index. The control variables, industry and time fixed effects are added in as before. The predicted values of long-term ownership $\widehat{L 3}$ are then substituted for L3 in the main regression to perform the second stage regression.

[Table 4] 
Results for the first stage regression are reported in first three columns of Table 4 . We observe that three of the index switching dummies have significant impacts on long-term ownership. These results are generally in line with Fich et al. (2015) . Columns (4)-(6) report the results of the second stage estimation results. We can see that the initial results of our main analysis stand. We still observe that long-term institutional ownership has a positive impact on firms' performance.

\section{Robustness tests and further discussion}

\subsection{Characteristics vs. incentives}

Numerous studies have found that some characteristics (legal, etc.) of institutional investors appear to have an impact in determining the influence of institutions on the firms in which they hold stock. To ensure that our findings are not purely driven by investors with specific characteristics, we follow the literature (Bushee 1998, 2001; Bushee and Noe 2000; Bushee and Goodman 2007) to classify investors into three categories and then look at the long-term holding effect of each type of investors on firm performance.

\section{Investors classified by fiduciary responsibility}

The first classification is based on fiduciary responsibilities. The Thomson Financial 13F database classifies investors into seven categories based on their fiduciary responsibilities. These categories comprise Public Pension Funds, Banks, Insurance, Corporate (Private) Pension Funds, University and Foundation Endowment, Investment Companies and Independent Investment Advisors. ${ }^{8}$ Investors with different fiduciary responsibility may be associated with different

\footnotetext{
${ }^{8}$ The original categories are provided by Thomson Financial, but the classification is imprecise since 1998, so we use Bushee's correction to update the classification into correct ones. Please see http://acct.wharton.upenn.edu/faculty/bushee/IIclass.html for detail.
} 
investment horizons (Ryan and Schneider, 2002; Cox et al. 2004; Neubaum and Zahra, 2006). In addition, they may have informal links which may lead to firms being differentially affected by investor action (Brickley et al. 1988; David et al. 1998; Cornett et al. 2007; Ferreira and Matos 2008; Elyasiani and Jia 2010). We follow the literature by aggregating investors into pressure insensitive investors (independent investment advisor, investment company and public pension fund, denoted as $I N D$ ) and pressure sensitive investors (bank, insurance and others, denoted as GRY) (Chen et al. 2007).

\section{Investors classified by investment style}

Institutional investors may have different investment styles. Some may prefer growth and be more interested in firms with high growth rates, lower dividend yield and higher market to book valuation. Other investors may prefer value and be more attracted by firms with higher dividend pay-outs and potentially undervalued. We follow Bushee's classification to divide investors into "Value", "Growth" and "Growth/Income" investors (the third category indicating that the investor cannot easily be attributed into either of the previous two types).

\section{Investors classified by portfolio turnover and bolding concentration}

Based on portfolio turnover and concentration, institutions can also be classified as transient investors, dedicated investors and quasi-indexers (Bushee and Goodman 2007; Aghion, et al. 2013).

To distinguish between monitoring incentive and investor characteristics, we calculate the longterm holding of each type of investor under the previous three classification schemes. We then examine the association between the long-term holdings of each type of investor and subsequent firm performance. If the monitoring incentive is a more important factor than investor characteristics in its effect on firm performance, we should observe distinguishable effects of long-term holdings of different investors on firm performance. In contrast, if the monitoring 
incentive is more important than investor characteristics, we should observe that the monitor incentive will dominate and that all types of investor will have similar impacts on firm value.

[Table 5]

Table 5 displays our findings. We regress all three performance measures on the long-term holdings of each type of institutional investor. For simplicity, we only report the second stage results of our 2SLS regressions. ${ }^{9}$ As can be observed from Table 5, long-term ownership of all types of investors is consistently positively correlated with firm future performances. Even for transient investors and grey investors who for one reason or other might be not be expected to be actively engaged with the firms in which they invest, an increase in the proportion of longterm holdings is still found to be value enhancing. These results clearly indicate that the institutional monitoring incentive is the most important factor contributing to firms' overall performance.

\subsection{Alternative measures of long-term ownership}

To ensure that our result is not subject to ambiguity concerning the horizon choice and variable stability, we test our result using alternative measures of long-term institutional ownership. The first alternative measure we use is L5, which defined as the ownership of institutional investors who holds shares in the firm for more than five years. This measure will lead to a stricter definition of long-term investors, as the monitoring incentive might be expected to be stronger when the observed holding period becomes longer. The second measure (LIOP) is the definition of long-term ownership used by Yan and Zhang (2009) in which long and short investors are classified according to their portfolio turnover. This measure will be noisier because although investors with lower portfolio turnover are more likely to have more long-term positions, a large proportion of their holdings could, for reasons explained earlier, be short term.

\footnotetext{
${ }^{9}$ The OLS estimation result is essentially similar and therefore not reported to save space.
} 
[Table 6]

The 2SLS estimation results are reported in Table 6 where the conclusions drawn from the baseline regression are largely supported by the regressions using alternative measures. When measured over longer horizons, long-term ownership is associated with higher ROA, Tobin's Q and EY (columns (4)-(6)). Even if we use the noisier measure LIOP, long-term ownership is still positively related to ROA and Tobin's Q although EY is no longer significant.

\subsection{Effect of short-term investors on firm performance}

Our analysis so far shows that holdings by long-term investors have a positive effect on firm value. A related question is; are short-term investors associated with a similar increase in firm profitability? Many studies argue that in general institutional investors have a significant impact on the firm (Yan and Zhang, 2009; Aghion et al. 2013). To examine whether more short-term institutional investors have a similar beneficial effect as long-term investors we need to apply our analysis to short-term institutions.

We construct three variables to measure ownership by short-term investors. Short-term investors' holding horizons are calculated as the overall holding period from first buying stock in the firm to selling. A holding period of less than one year is classified as S1, a two-year or less is classified as S2. We also use portfolio turnover, classifying investors whose portfolio turnover are among the highest $30 \%$ of all investors as SIOP. We then regress firm performance on the ownership of these investors and control variables. As with the analysis of long-term investors, we continue to apply 2SLS regression.

The effect of short-term investors on firm performance are reported in Table 7 . It can be seen that short-term institutional ownership is associated negatively with subsequent firm performance. Higher short-term ownership will lead to lower ROA, lower Tobin's Q and lower 
EY. Moreover, the negative impact appears to become weaker when the horizon used to define short-term holders become longer.

Our findings shows clear evidence that a positive holding performance relationship only exists when the holdings are long term and short-term holdings are negatively associated with firm performance. There are several possible reasons that why short-term holdings may have a negative effect. The first reason is that short-term investors may not have enough monitoring incentive. Chen et al. (2007) point out that monitoring is optimal for investors when the benefits exceed the costs in in the long term. For short-term holdings, since the costs are higher than the benefits, not to monitor might be a better choice. A lack of monitoring incentive could lead to higher agency costs and, therefore, lower performance. The second potential reason is that investors could predict firm performance. When they only hold stocks for short period of time, they may already foresee worse performance in the future. ${ }^{10}$ The third potential reason is that short-term investors may force the firm to adopt short-term oriented policies to maximize shortterm gain while sacrificing long-term growth potential. Even though we adopted a 2SLS approach to mitigate any endogeneity problem, we acknowledge the limitation that we did not disentangle the three different hypotheses completely. Since our main purpose is to focus on the monitoring effect of long-term investors, we decide to leave the further discussion about shortterm holding for future studies.

\subsection{Persistence of firm performance and institutional holdings}

There is a concern that the positive relation between the long-term holdings of institutional investors and firm performance may only simply be mirroring the fact that both long-term holdings and firm performance are persistent. ${ }^{11}$ We have made some efforts to address this concern. First, in our main regression, the current performance of firms has been controlled for, therefore the effect of holdings on performance should be independent of the effect of past

\footnotetext{
${ }^{10}$ We thank the referee for pointing this out.

${ }^{11}$ We thank the referee for pointing this out.
} 
performance. Second, it is likely that the relation between past performance on future performance is not linear. To alleviate this concern, we double sort all the firms into 25 different portfolios according to the quintile of current firm performance and current long-term institutional holdings. The average performances of firms in the $t+1$ to $t+4$ quarter in each portfolio are shown in Table 8. Columns (1)-(5) in each panel shows the future performance of the firm with a current performance rank from low to high while rows (1)-(5) show the future performance of firms with long-term institutional ownership ranking from low to high.

As we can see in each row of Table 8, firms with better current performance do not necessarily outperform in the future. For example, a firm with high current Tobin's Q may actually have a lower Tobin's Q in the next year. However, in each column, we can see that no matter the rank of current firm performance, firms with a higher long-term institutional holding ranking consistently outperform firms with a low long-term holding ranking. These findings provide additional evidence that performance persistence is not the main driver of our results.

\section{Conclusion}

The beneficial effects on firm performance resulting from the monitoring of their management by institutional investors has long been recognized. In this paper, we have endeavored to drill down to a finer analysis of the type of institutional behaviour most closely responsible for any improvement in managerial decision making, by identifying the holding period of institutions of their actual holding behavior in each firm in which they hold stock. We define long-term investors on the basis that they have already held stock in each firm for a specified period and argue that the longer the investor holds stock in a company, the greater the incentive for the investor to actively engage in monitoring the performance of the firm management. We find that an increase in the proportion of long-term investors does indeed lead to better performance as measured by ROA, Tobin's Q and EY. We conduct additional tests to guard against any misinterpretation of the results on the basis of endogeneity and we examine the robustness of our 
results by trying different definitions of long term, including the classification of the fiduciary basis, the links between the investors and the firms in which they invest. Our conclusions remain consistent across the range of additional tests and techniques used. Finally, we look at short-term institutional investors and find, using similar techniques and tests, that they are not associated with better performance but more typically worse. This is consistent with our prior belief that short-term investors would have less incentive than long-term investors to actively engage with the management of the firms in which they hold stock and reinforces the belief that a strong basis of long-term institutional investor ownership contributes to an improvement in firm management and performance. 


\section{References}

Aghion, P., J. Van Reenen, and L. Zingales. 2013. Innovation and Institutional Ownership. The American Economic Review 103:277-304.

Appel, I. R., T. A. Gormley, and D. B. Keim. 2016a. Passive Investors, Not Passive Owners. Journal of Financial Economics 121:111-41.

Appel, I. R., T. A. Gormley, and D. B. Keim. 2016b. Passive Investors, Not Passive Owners. Journal of Financial Economics 121:111-41.

Armitage, S., A. Haig, and L. Hodgkinson. Is an Investing Institution One Shareholder or a Collection of Separate Funds? Corporate Governance: An International Review 25:20-40.

Attig, N., S. Cleary, S. El Ghoul, and O. Guedhami. 2012. Institutional Investment Horizon and Investment-cash Flow Sensitivity. Journal of Banking \& Finance 36:1164-80.

Attig, N., S. Cleary, S. El Ghoul, and O. Guedhami. 2013. Institutional Investment Horizons and the Cost of Equity Capital. Financial Management 42:441-77.

Bradley, M., A. Brav, I. Goldstein, and W. Jiang. 2010. Activist Arbitrage: A Study of Open-Ending Attempts of Closed-End Funds. Journal of Financial Economics 95:1-19.

Brav, A., W. Jiang, and H. Kim. 2015. The Real Effects of Hedge Fund Activism: Productivity, Asset Allocation, and Labor Outcomes. The Review of Financial Studies 28:2723-69.

Brav, A., W. Jiang, F. Partnoy, and R. Thomas. 2008. Hedge Fund Activism, Corporate Governance, and Firm Performance. The Journal of Finance 63:1729-75.

Brickley, J. A., R. C. Lease, and C. J. Smith. 1988. Ownership Structure and Voting on Antitakeover Amendments. Journal of Financial Economics 20:267-91.

Bushee, B. J. 1998. The Influence of Institutional Investors on Myopic R\&D Investment Behavior. The Accounting Review 73:305-33.

Bushee, B. J. 2001. Do Institutional Investors Prefer Near-Term Earnings over Long-Run Value?*. Contemporary Accounting Research 18:207-46.

Bushee, B. J., and T. H. Goodman. 2007. Which Institutional Investors Trade Based on Private Information About Earnings and Returns? Journal of Accounting Research 45:289-321. 
Bushee, B. J., and C. F. Noe. 2000. Corporate Disclosure Practices, Institutional Investors, and Stock Return Volatility. Journal of Accounting Research 38:171-202.

Cai, C. X., D. Hillier, and J. Wang. 2016. The Cost of Multiple Large Shareholders. Financial Management 45:401-30

Cella, C. 2014. Institutional Investors and Corporate Investment. SSRN Scholarly Paper, Rochester, NY: Social Science Research Network.

Cella, C., A. Ellul, and M. Giannetti. 2013. Investors' Horizons and the Amplification of Market Shocks. Review of Financial Studies 26:1607-48.

Chen, X., J. Harford, and K. Li. 2007a. Monitoring: Which Institutions Matter? Journal of Financial Economics 86:279-305.

Chen, X., J. Harford, and K. Li. 2007b. Monitoring: Which Institutions Matter? Journal of Financial Economics 86:279-305.

Chichernea, D. C., A. Petkevich, and B. B. Zykaj. 2015. Idiosyncratic Volatility, Institutional Ownership, and Investment Horizon. European Financial Management 21:613-45.

Chung, R., S. Fung, and S.-Y. K. Hung. 2012. Institutional Investors and Firm Efficiency of Real Estate Investment Trusts. The Journal of Real Estate Finance and Economics 45:171-211.

Cornett, M. M., A. J. Marcus, A. Saunders, and H. Tehranian. 2007. The Impact of Institutional Ownership on Corporate Operating Performance. Journal of Banking \& Finance 31:1771-94.

Cox, P., S. Brammer, and A. Millington. 2004. An Empirical Examination of Institutional Investor Preferences for Corporate Social Performance. Journal of Business Ethics 52:27-43.

Crane, A. D., S. Michenaud, and J. P. Weston. 2016. The Effect of Institutional Ownership on Payout Policy: Evidence from Index Thresholds. Review of Financial Studies 29:1377-1408.

Cronqvist, H., and R. Fahlenbrach. 2009. Large Shareholders and Corporate Policies. Review of Financial Studies 22:3941-76.

David, P., R. Kochhar, and E. Levitas. 1998. The Effect of Institutional Investors on the Level and Mix of Ceo Compensation. Academy of Management Journal 41:200-208.

Edmans, A. 2014. Blockholders and Corporate Governance. The Annual Review of Financial Economics is $6: 23-50$. 
Elyasiani, E., and J. Jia. 2010. Distribution of Institutional Ownership and Corporate Firm Performance. Journal of Banking \& Finance 34:606-20.

Ferreira, M. A., and P. Matos. 2008. The Colors of Investors' Money: The Role of Institutional Investors around the World. Journal of Financial Economics 88. Darden - JFE Conference Volume: Capital Raising in Emerging Economies:499-533.

Fich, E. M., J. Harford, and A. L. Tran. 2015. Motivated Monitors: The Importance of Institutional Investors' Portfolio Weights. Journal of Financial Economics 118:21-48.

Gaspar, J., and M. Massa. 2006. Idiosyncratic Volatility and Product Market Competition. The Journal of Business 79:3125-52.

Gaspar, J.-M., M. Massa, and P. Matos. 2005. Shareholder Investment Horizons and the Market for Corporate Control. Journal of Financial Economics 76:135-65.

Giannetti, M., and X. Yu. 2018. Adapting to Radical Change: The Benefits of Short-Horizon Investors. SSRN Scholarly Paper, Rochester, NY: Social Science Research Network.

Kacperczyk, M., S. V. Nieuwerburgh, and L. Veldkamp. A Rational Theory of Mutual Funds' Attention Allocation. Econometrica 84:571-626.

La Porta, R., F. Lopez-De-Silanes, and A. Shleifer. 1999. Corporate Ownership Around the World. The Journal of Finance 54:471-517.

Luong, L. H., F. Moshirian, L. H. G. Nguyen, X. Tian, and B. Zhang. 2016. How Do Foreign Institutional Investors Enhance Firm Innovation? SSRN Scholarly Paper, Rochester, NY: Social Science Research Network.

McCAHERY, J. A., Z. Sautner, and L. T. Starks. 2016. Behind the Scenes: The Corporate Governance Preferences of Institutional Investors. The Journal of Finance :n/a-n/a.

Neubaum, D. O., and S. A. Zahra. 2006. Institutional Ownership and Corporate Social Performance: The Moderating Effects of Investment Horizon, Activism, and Coordination. Journal of Management 32:108-31.

Schmidt, C., and R. Fahlenbrach. 2016. Do Exogenous Changes in Passive Institutional Ownership Affect Corporate Governance and Firm Value? SSRN Scholarly Paper, Rochester, NY: Social Science Research Network.

Sims, C. A. 2003. Implications of Rational Inattention. Journal of Monetary Economics 50. Swiss National Bank/Study Center Gerzensee Conference on Monetary Policy under Incomplete Information:665-90. 
Ward, C. W. R., C. Yin, and Y. Zeng. 2017. Motivated Monitoring Institutional Investors and Firm Investment Efficiency. SSRN Scholarly Paper, Rochester, NY: Social Science Research Network.

Ward, C., C. Yin, and Y. Zeng. 2018. Institutional Investor Monitoring Motivation and the Marginal Value of Cash. Journal of Corporate Finance 48:49-75.

Wurgler, J. 2010. On the Economic Consequences of Index-Linked Investing. SSRN Scholarly Paper, Rochester, NY: Social Science Research Network.

Yan, X. (Sterling), and Z. Zhang. 2009. Institutional Investors and Equity Returns: Are Short-Term Institutions Better Informed? Review of Financial Studies 22:893-924. 


\section{Tables and figures}

Table 1 Summary statistics

Table 1 shows which type of investors tend to be long-term investors. The sample period is 1982-2013. All firms have completed information in CRSP and the COMPUSTAT database. Institutional ownership data is from the Thomson Financial Institutional Holding database. Average Holdings are the average percentage holdings of each type of investor in each company. Average Long-Term Holdings are the average percentage holdings of each type of investor in each company which exceeds three years. Proportion of Long-Term Holdings are the ratio of longterm holding of each type of investor to the average holding of this type of investor. Classifications are provided by Bushee (1998).

\begin{tabular}{|c|c|c|c|c|}
\hline & Average Holdings & $\begin{array}{l}\text { Average L } \\
\text { Holdings }\end{array}$ & $\begin{array}{l}\text { Proportion } \\
\text { Long- } \\
\text { Holdings }\end{array}$ & $\begin{array}{r}\text { of } \\
\text { term }\end{array}$ \\
\hline \multicolumn{5}{|c|}{ Investors classified by portfolio diversification and turnover: } \\
\hline Dedicated Investors & $4.61 \%$ & $2.16 \%$ & $46.92 \%$ & \\
\hline Quasi-Indexer & $17.53 \%$ & $9.53 \%$ & $54.37 \%$ & \\
\hline Transient Investors & $7.63 \%$ & $1.93 \%$ & $25.33 \%$ & \\
\hline \multicolumn{5}{|l|}{ Investors classified by style: } \\
\hline Value Style & $9.77 \%$ & $4.47 \%$ & $45.73 \%$ & \\
\hline Growth \& Income & $13.37 \%$ & $6.70 \%$ & $50.08 \%$ & \\
\hline Growth Style & $6.95 \%$ & $2.41 \%$ & $34.68 \%$ & \\
\hline \multicolumn{5}{|c|}{ Investors classified by fiduciary duties: } \\
\hline Indep. Investment Advisors & $17.36 \%$ & $6.63 \%$ & $38.18 \%$ & \\
\hline Banks & $5.17 \%$ & $3.02 \%$ & $58.46 \%$ & \\
\hline Investment Companies & $4.03 \%$ & $2.16 \%$ & $53.59 \%$ & \\
\hline Insurance Companies & $1.79 \%$ & $0.93 \%$ & $51.69 \%$ & \\
\hline Public Pension Funds & $0.86 \%$ & $0.46 \%$ & $53.19 \%$ & \\
\hline Miscellaneous & $0.75 \%$ & $0.28 \%$ & $37.73 \%$ & \\
\hline Corporate Pension Funds & $0.31 \%$ & $0.11 \%$ & $34.17 \%$ & \\
\hline University and Fundaments & $0.12 \%$ & $0.05 \%$ & $39.12 \%$ & \\
\hline All institutional investors: & $32.87 \%$ & $15.22 \%$ & $46.30 \%$ & \\
\hline
\end{tabular}


Table 2 Descriptive statistics

Table 2 reports the summary statistics of variables used in the regression analysis. The sample period is from 1982-2013.All firms have completed information in CRSP and the COMPUSTAT database. The institutional ownership data is from the Thomson Financial Institutional Holding database. The number of observations, mean, standard deviation, minimum, $25^{\text {th }}$ percentile, median, $75^{\text {th }}$ percentile and maximum are displayed from left to right. Detailed definitions of all variables can be found in Appendix A. All the missing data in the ownership, control variables and instrumental variables are filled with 0 . $\mathrm{ROA}_{\mathrm{i}, \mathrm{t}+1, \mathrm{t}+4, \mathrm{~TB}}, \mathrm{~TB}_{\mathrm{i}, \mathrm{t}+1, \mathrm{t}+4}$

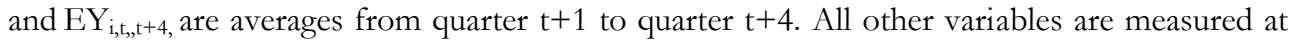
quarter t.

\begin{tabular}{|c|c|c|c|c|c|c|c|c|}
\hline Variable & $\mathrm{N}$ & Mean & S.D. & Min & $25 \%$ & $50 \%$ & $75 \%$ & Max \\
\hline \multicolumn{9}{|c|}{ Firm performance: } \\
\hline ROA & 570639 & -0.01 & 0.05 & -0.25 & -0.01 & 0.00 & 0.01 & 0.06 \\
\hline TBQ & 529308 & 0.33 & 1.20 & -1.25 & -0.26 & 0.00 & 0.47 & 6.25 \\
\hline EP & 571536 & -0.01 & 0.06 & -0.40 & -0.01 & & 0.01 & 0.08 \\
\hline \multicolumn{9}{|c|}{ Long-term ownership measures: } \\
\hline L3 & 640784 & 0.15 & 0.19 & 0.00 & 0.00 & 0.06 & 0.25 & 0.99 \\
\hline L5 & 640784 & 0.10 & 0.15 & 0.00 & 0.00 & 0.00 & 0.14 & 0.97 \\
\hline LIOP & 640784 & 0.09 & 0.10 & 0.00 & 0.01 & 0.06 & 0.14 & 1.00 \\
\hline \multicolumn{9}{|c|}{ Long-term ownership measures: } \\
\hline L3IND & 638385 & 0.10 & 0.13 & 0.00 & 0.00 & 0.04 & 0.16 & 0.95 \\
\hline L3GRY & 638385 & 0.05 & 0.08 & 0.00 & 0.00 & 0.01 & 0.08 & 0.95 \\
\hline L3QIX & 638385 & 0.11 & 0.15 & 0.00 & 0.00 & 0.03 & 0.16 & 0.96 \\
\hline L3DED & 638385 & 0.03 & 0.06 & 0.00 & 0.00 & 0.00 & 0.02 & 0.93 \\
\hline L3TRA & 638385 & 0.02 & 0.04 & 0.00 & 0.00 & 0.00 & 0.02 & 0.96 \\
\hline L3VAL & 638385 & 0.05 & 0.08 & 0.00 & 0.00 & 0.01 & 0.07 & 0.96 \\
\hline L3GRO & 638385 & 0.03 & 0.06 & 0.00 & 0.00 & 0.00 & 0.03 & 0.92 \\
\hline L3GI & 638385 & 0.08 & 0.11 & 0.00 & 0.00 & 0.02 & 0.11 & 0.98 \\
\hline \multicolumn{9}{|c|}{ Control variables: } \\
\hline LOGMV & 640784 & 18.97 & 1.94 & 15.24 & 17.54 & 18.78 & 20.22 & 24.15 \\
\hline DTA & 640784 & 0.18 & 0.20 & 0.00 & 0.00 & 0.12 & 0.31 & 0.86 \\
\hline AGE & 640784 & 14.28 & 12.08 & 1.00 & 5.00 & 11.00 & 20.00 & 64.00 \\
\hline TOV & 640784 & 0.10 & 0.11 & 0.00 & 0.03 & 0.06 & 0.12 & 0.65 \\
\hline CAPX & 640784 & 0.01 & 0.03 & -0.19 & -0.01 & 0.00 & 0.01 & 0.30 \\
\hline \multicolumn{9}{|c|}{ Instrument variables: } \\
\hline R1TR2 & 395045 & 0.01 & 0.09 & 0.00 & 0.00 & 0.00 & 0.00 & 1.00 \\
\hline R2TR1 & 395045 & 0.01 & 0.10 & 0.00 & 0.00 & 0.00 & 0.00 & 1.00 \\
\hline R2TN & 395045 & 0.04 & 0.18 & 0.00 & 0.00 & 0.00 & 0.00 & 1.00 \\
\hline NTR2 & 395045 & 0.06 & 0.24 & 0.00 & 0.00 & 0.00 & 0.00 & 1.00 \\
\hline
\end{tabular}


Table 3 Baseline regression, long-term ownership and firm performance Table 3 reports the panel regression coefficients of the baseline regression. The dependent variables are ROA, Tobin's $Q$ and EY, measured as the average from quarter $\mathrm{t}+1$ to $\mathrm{t}+4$. The sample period is 1982-2013. All the independent variables are measured at time $t$. The missing data in the independent variables are filled with $0 .{ }^{* * *}$, **, and $*$ denote statistical significance at the $1 \%, 5 \%$ and $10 \%$ levels, respectively. The industry (2-digit SIC number) and quarter fixed effects are in all the regressions. Standard errors are clustered at the firm level. Detailed definitions of variables are in Appendix A.

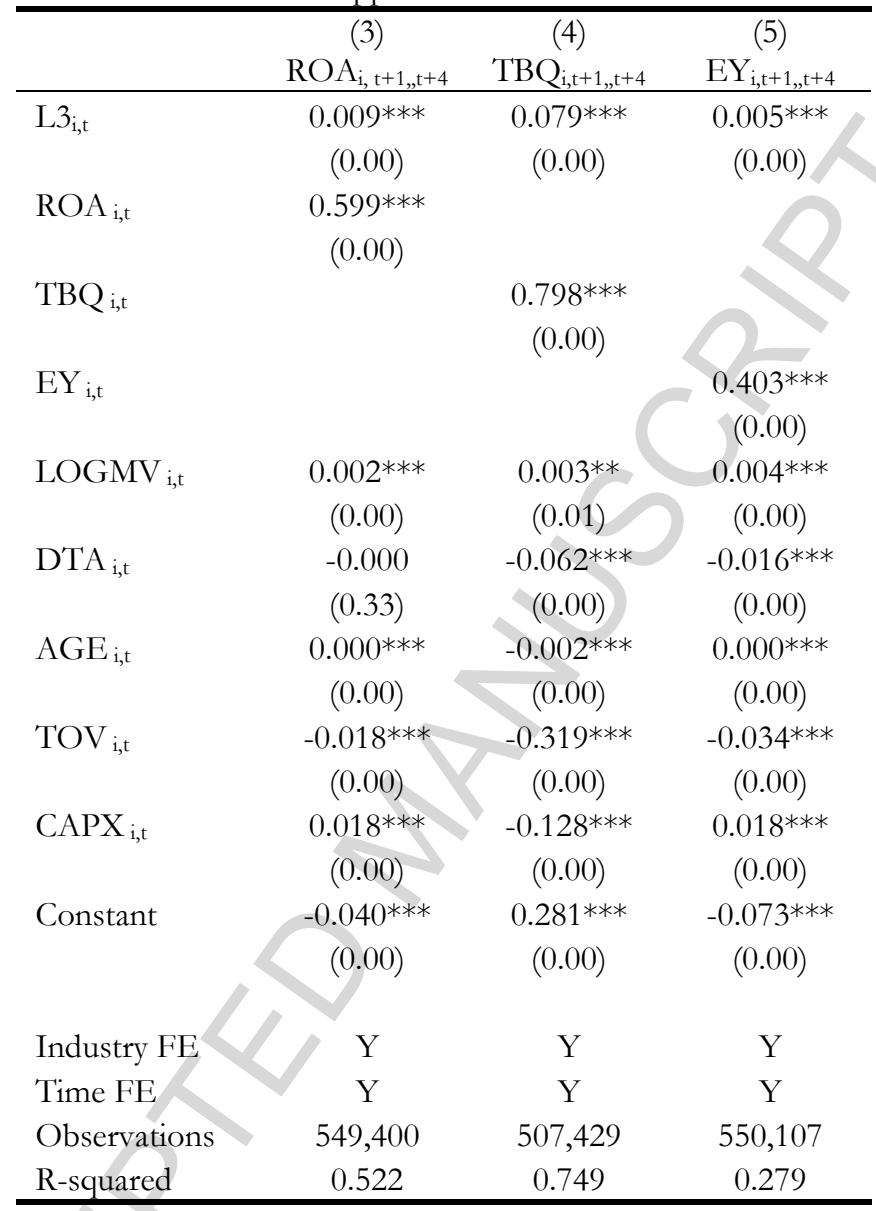

Robust $\mathrm{p}$-value in parentheses.

*** $\mathrm{p}<0.01,{ }^{* *} \mathrm{p}<0.05,{ }^{*} \mathrm{p}<0.1$. 
Figure 1 Long-term ownership and firm performance in the longer future

Figure 1 shows the coefficients of L3 in the regressions of future firm performance on the longterm ownership and control variables which include LOGMV, DTA, AGE, TOV, CAPX, industry (2-digit SIC) and time fixed effect( quarter). Firm performance is measured at quarter $\mathrm{t}+4, \mathrm{t}+8$, $\mathrm{t}+12, \mathrm{t}+16$ and $\mathrm{t}+20$ as shown in the horizontal axis. The coefficients of long-term ownership (L3) are labeled on the vertical axis. The three parts of the figure show ROA, Tobin's Q and EY from top to bottom. The standard errors are clustered at the firm level and the red dashed line shows the confidence interval of estimates at the $95 \%$ level. Detailed definitions of variables are in Appendix A.

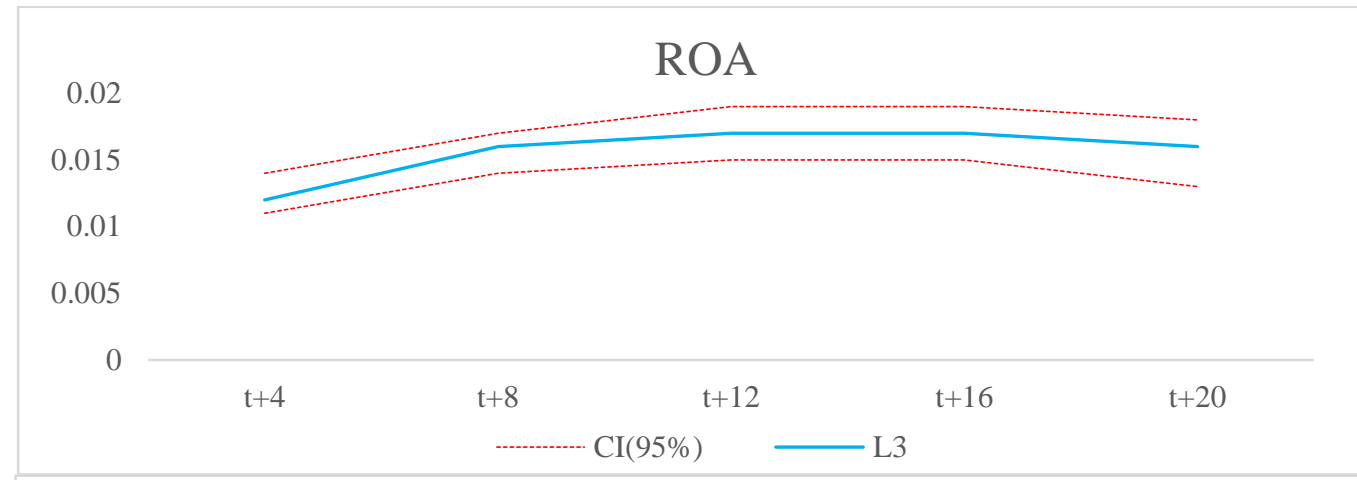

0.3

Tobin's Q

0.25

0.2

0.15

0.1

0.05

0

$\mathrm{t}+4$

$\mathrm{t}+8$

$\mathrm{t}+12$

$\mathrm{t}+16$

$\mathrm{t}+20$

CI $(95 \%)$

L3

0.025

Earning Yield

0.02

0.015

0.01

0.005

0

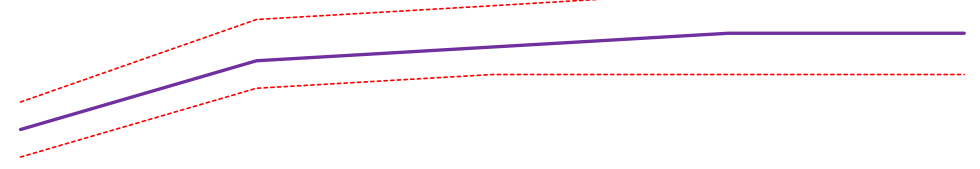

$\mathrm{t}+4$

$\mathrm{t}+8$

$\mathrm{CI}(95 \%)^{\mathrm{t}+12}$

$\mathrm{t}+16$

$t+20$ 
Table 4 2SLS estimation, long-term ownership and firm performance

Table 4 reports the 2SLS estimation results of firm performance on long-term ownership. The sample period is 1995-2013 when the instrumental variable is available. Columns (1)-(3) show the result of our first step estimation. The fitted values of L3(IVL3) is then used as substitutes in the second stage regressions (columns (4)-(6)). All the independent variables are measured at time t. The missing data in the independent variables are filled with $0 .{ }^{* * *}, * *$, and $*$ denote statistical significance at $1 \%, 5 \%$, and $10 \%$ levels, respectively. Industry (2-digit SIC number) and quarter fixed effects are in all the regressions. The standard errors are clustered at the firm level. Detailed definitions of variables are in Appendix A.

\begin{tabular}{|c|c|c|c|c|c|c|}
\hline \multirow[b]{3}{*}{ VARIABLES } & \multicolumn{3}{|l|}{ First Stage } & \multicolumn{3}{|l|}{ Second Stage } \\
\hline & (1) & $(2)$ & (3) & (4) & (5) & (6) \\
\hline & L3 & L3 & L3 & $\mathrm{ROA}_{\mathrm{i}, \mathrm{t}+1, \mathrm{t}+4}$ & $\mathrm{TBQ}_{\mathrm{i}, \mathrm{t}+1, \mathrm{t}+4}$ & $E Y_{i, t+1, t+4}$ \\
\hline IVL3 ${ }_{i, t}$ & & & & $\begin{array}{c}0.019 * * * \\
(0.00)\end{array}$ & $\begin{array}{c}1.127^{* * * *} \\
(0.00)\end{array}$ & $\begin{array}{c}0.011 * * \\
(0.04)\end{array}$ \\
\hline R1TR2 $2_{i, t}$ & $\begin{array}{c}0.119 * * * \\
(0.00)\end{array}$ & $\begin{array}{c}0.103^{* * *} \\
(0.00)\end{array}$ & $\begin{array}{c}0.117^{* * *} \\
(0.00)\end{array}$ & & & \\
\hline R2TR1 $1_{i, t}$ & $\begin{array}{c}-0.004 \\
(0.45)\end{array}$ & $\begin{array}{l}0.010 \\
(0.11)\end{array}$ & $\begin{array}{r}-0.001 \\
(0.85)\end{array}$ & & & \\
\hline $\mathrm{R} 2 \mathrm{TN}_{\mathrm{i}, \mathrm{t}}$ & $\begin{array}{c}-0.008^{* * *} \\
(0.00)\end{array}$ & $\begin{array}{c}-0.016^{* * *} \\
(0.00)\end{array}$ & $\begin{array}{c}-0.010^{* * *} \\
(0.00)\end{array}$ & & & \\
\hline NTR2 ${ }_{i, t}$ & $\begin{array}{c}-0.097^{* * *} \\
(0.00)\end{array}$ & $\begin{array}{c}-0.090^{* * *} \\
(0.00)\end{array}$ & $\begin{array}{c}-0.097^{* * *} \\
(0.00)\end{array}$ & & & \\
\hline $\mathrm{ROA}_{i, t}$ & $\begin{array}{c}0.108^{* * *} \\
(0.00)\end{array}$ & & & $\begin{array}{c}0.616^{* * *} \\
(0.00)\end{array}$ & & \\
\hline $\mathrm{TBQ}_{\mathrm{i}, \mathrm{t}}$ & & $\begin{array}{c}-0.018^{* * *} \\
(0.00)\end{array}$ & & & $\begin{array}{c}0.807 * * * \\
(0.00)\end{array}$ & \\
\hline$E P_{i, t}$ & & & $\begin{array}{c}-0.033^{* * *} \\
(0.00)\end{array}$ & & & $\begin{array}{c}0.400^{* * *} \\
(0.00)\end{array}$ \\
\hline LOGMV $_{i, t}$ & $\begin{array}{c}0.052^{* * *} \\
(0.00)\end{array}$ & $\begin{array}{c}0.056^{* * *} \\
(0.00)\end{array}$ & $\begin{array}{c}0.053^{* * *} \\
(0.00)\end{array}$ & $\begin{array}{c}0.001^{* * * *} \\
(0.00)\end{array}$ & $\begin{array}{c}-0.054^{* * *} \\
(0.00)\end{array}$ & $\begin{array}{c}0.004^{* * *} \\
(0.00)\end{array}$ \\
\hline DTA $_{i, t}$ & $\begin{array}{c}0.028^{* * *} \\
(0.00)\end{array}$ & $\begin{array}{c}0.014^{* *} \\
(0.01)\end{array}$ & $\begin{array}{c}0.025^{* * *} \\
(0.00)\end{array}$ & $\begin{array}{l}0.001 \\
(0.12)\end{array}$ & $\begin{array}{c}-0.067^{* * *} \\
(0.00)\end{array}$ & $\begin{array}{c}-0.015^{* * *} \\
(0.00)\end{array}$ \\
\hline $\mathrm{AGE}_{i, t}$ & $\begin{array}{c}0.004^{* * *} \\
(0.00)\end{array}$ & $\begin{array}{c}0.004^{* * *} \\
(0.00)\end{array}$ & $\begin{array}{c}0.004^{* * *} \\
(0.00)\end{array}$ & $\begin{array}{c}0.000^{* * *} \\
(0.00)\end{array}$ & $\begin{array}{c}-0.006^{* * *} \\
(0.00)\end{array}$ & $\begin{array}{c}0.000^{* * *} \\
(0.00)\end{array}$ \\
\hline $\operatorname{TOV}_{i, t}$ & $\begin{array}{c}0.045^{* * *} \\
(0.00)\end{array}$ & $\begin{array}{c}0.061^{* * *} \\
(0.00)\end{array}$ & $\begin{array}{c}0.039 * * * \\
(0.00)\end{array}$ & $\begin{array}{c}-0.017 \text { *** } \\
(0.00)\end{array}$ & $\begin{array}{c}-0.377^{* * *} \\
(0.00)\end{array}$ & $\begin{array}{c}-0.034^{* * *} \\
(0.00)\end{array}$ \\
\hline CAPX $_{i, t}$ & $\begin{array}{c}-0.118^{* * *} \\
(0.00)\end{array}$ & $\begin{array}{c}-0.084^{* * *} \\
(0.00)\end{array}$ & $\begin{array}{c}-0.114^{* * *} \\
(0.00)\end{array}$ & $\begin{array}{c}0.021 * * * \\
(0.00)\end{array}$ & $\begin{array}{r}-0.047 \\
(0.37)\end{array}$ & $\begin{array}{c}0.018^{* * *} \\
(0.00)\end{array}$ \\
\hline Constant $_{i, t}$ & $\begin{array}{c}-0.963^{* * *} \\
(0.00)\end{array}$ & $\begin{array}{c}-1.015^{* * *} \\
(0.00)\end{array}$ & $\begin{array}{c}-0.984 * * * \\
(0.00)\end{array}$ & $\begin{array}{c}-0.069 * * * \\
(0.00)\end{array}$ & $\begin{array}{c}1.937 * * * \\
(0.00)\end{array}$ & $\begin{array}{c}-0.107 * * * \\
(0.00)\end{array}$ \\
\hline Industry FE & Y & $\mathrm{Y}$ & $\mathrm{Y}$ & $\mathrm{Y}$ & Y & $\mathrm{Y}$ \\
\hline Time FE & Y & Y & Y & $\mathrm{Y}$ & $\mathrm{Y}$ & $\mathrm{Y}$ \\
\hline Observations & 360,431 & 337,295 & 364,650 & 344,618 & 321,106 & 348,949 \\
\hline R-squared & 0.542 & 0.558 & 0.542 & 0.552 & 0.731 & 0.283 \\
\hline
\end{tabular}


Table 5 Type of long-term investors and firm performance

Panel A of Table 5 reports the 2SLS estimation results of the future ROA on different types of long-term ownership. The sample period is 1995-2013 when the instrumental variable is available. Columns (1)-(8) represent the regressions of ROA on the long-term ownership of independent investors, grey investors, quasi-indexers, dedicated institutional investors, transient investors value investors and growth investors, respectively. The instrument variables are R1TR2, R2TR1, R2TN and NTR2. The first stage estimation is not displayed for simplicity. The fitted values of long-term ownerships are used as substitutes in the second stage regressions (denoted with a leading"). All the independent variables are measured at time t. The missing data in independent variables are filled with $0 . * * *, * *$, and $*$ denote statistical significance at $1 \%, 5 \%$, and $10 \%$ levels, respectively. Industry (2-digit SIC number) and quarter fixed effects are in all the regressions. The standard errors are clustered at the firm level. Detailed definitions of variables are in Appendix A.

\begin{tabular}{|c|c|c|c|c|c|c|c|c|}
\hline & $\begin{array}{l}\text { (1) } \\
\mathrm{ROA}_{\mathrm{i}, \mathrm{t}+1, \mathrm{t}+4}\end{array}$ & $\begin{array}{l}\text { (2) } \\
\mathrm{ROA}_{\mathrm{i}, \mathrm{t}+1, \mathrm{t}+4}\end{array}$ & $\begin{array}{l}\text { (3) } \\
\text { ROA }_{i, t+1, t+4}\end{array}$ & $\begin{array}{l}\text { (4) } \\
\mathrm{ROA}_{\mathrm{i}, \mathrm{t}+1, \mathrm{t}+4}\end{array}$ & $\begin{array}{l}\text { (5) } \\
\mathrm{ROA}_{\mathrm{i}, \mathrm{t}+1, \mathrm{t}+4}\end{array}$ & $\begin{array}{l}\text { (6) } \\
\mathrm{ROA}_{\mathrm{i}, \mathrm{t}+1, \mathrm{t}+4}\end{array}$ & $\begin{array}{l}(7) \\
\mathrm{ROA}_{\mathrm{i}, \mathrm{t}+1, \mathrm{t}+4}\end{array}$ & $\begin{array}{l}(8) \\
\mathrm{ROA}_{\mathrm{i}, \mathrm{t}+1, \mathrm{t}+4}\end{array}$ \\
\hline IVL3IND $_{i, t}$ & $\begin{array}{l}0.027^{* * *} \\
(0.00)\end{array}$ & & & & & & & \\
\hline IVL3GRY ${ }_{i, t}$ & & $\begin{array}{l}0.060 * * * \\
(0.00)\end{array}$ & & & & & & \\
\hline IVL3QIX $_{i, t}$ & & & $\begin{array}{l}0.025^{* * *} \\
(0.00)\end{array}$ & & & & & \\
\hline IVL3DED $_{\mathrm{i}, \mathrm{t}}$ & & & & $(0.00)$ & & & & \\
\hline IVL3TRA $_{i, t}$ & & & & & & & & \\
\hline IVL3VAL $_{i, t}$ & & & & & & $\begin{array}{l}0.061 * * * \\
(0.00)\end{array}$ & & \\
\hline IVL3GRO $_{i, t}$ & & & & & & & $\begin{array}{l}0.096^{* * *} \\
(0.00)\end{array}$ & \\
\hline IVL3GI $\mathrm{i}_{\mathrm{i}, \mathrm{t}}$ & & & & & & & & $\begin{array}{l}0.036 * * * \\
(0.00)\end{array}$ \\
\hline $\mathrm{ROA}_{i, t}$ & $\begin{array}{l}0.002^{* * *} \\
(0.00)\end{array}$ & $\begin{array}{l}0.001 * * * \\
(0.00)\end{array}$ & $\begin{array}{l}0.001 * * * \\
(0.00)\end{array}$ & $\begin{array}{l}0.001 * * * \\
(0.00)\end{array}$ & $\begin{array}{l}0.001 * * * \\
(0.00)\end{array}$ & $\begin{array}{l}0.002^{* * *} \\
(0.00)\end{array}$ & $\begin{array}{l}0.001 * * * \\
(0.00)\end{array}$ & $\begin{array}{l}0.001^{* * *} \\
(0.00)\end{array}$ \\
\hline LOGMV $_{i, t}$ & $\begin{array}{l}0.001 * \\
(0.09)\end{array}$ & $\begin{array}{l}0.001 \\
(0.20)\end{array}$ & $\begin{array}{l}0.001^{*} \\
(0.06)\end{array}$ & $\begin{array}{l}0.000 \\
(0.58)\end{array}$ & $\begin{array}{l}0.001 \\
(0.27)\end{array}$ & $\begin{array}{l}0.001 \\
(0.12)\end{array}$ & $\begin{array}{l}0.001^{*} \\
(0.05)\end{array}$ & $\begin{array}{l}0.001 \\
(0.13)\end{array}$ \\
\hline DTA $_{i, t}$ & $\begin{array}{l}0.000^{* * *} \\
(0.00)\end{array}$ & $\begin{array}{l}0.000 \\
(0.11)\end{array}$ & $\begin{array}{l}0.000^{* * *} \\
(0.00)\end{array}$ & $\begin{array}{l}0.000^{* * *} \\
(0.00)\end{array}$ & $\begin{array}{l}0.000 * * * \\
(0.00)\end{array}$ & $\begin{array}{l}0.000 \\
(0.18)\end{array}$ & $\begin{array}{l}0.000^{* * *} \\
(0.00)\end{array}$ & $\begin{array}{l}0.000^{* * *} \\
(0.00)\end{array}$ \\
\hline $\mathrm{AGE}_{\mathrm{i}, \mathrm{t}}$ & $\begin{array}{l}-0.017^{* * *} \\
(0.00)\end{array}$ & $\begin{array}{l}-0.018^{* * *} \\
(0.00)\end{array}$ & $\begin{array}{l}-0.018^{* * *} \\
(0.00)\end{array}$ & $\begin{array}{l}-0.011^{* * *} \\
(0.00)\end{array}$ & $\begin{array}{l}-0.019^{* * *} \\
(0.00)\end{array}$ & $\begin{array}{l}-0.016^{* * *} \\
(0.00)\end{array}$ & $\begin{array}{l}-0.016^{* * *} \\
(0.00)\end{array}$ & $\begin{array}{l}-0.018^{* * *} \\
(0.00)\end{array}$ \\
\hline $\operatorname{TOV}_{\mathrm{i}, \mathrm{t}}$ & $\begin{array}{l}0.020^{* * *} \\
(0.00)\end{array}$ & $\begin{array}{l}0.021 * * * \\
(0.00)\end{array}$ & $\begin{array}{l}0.020^{* * *} \\
(0.00)\end{array}$ & $\begin{array}{l}0.021^{* * *} \\
(0.00)\end{array}$ & $\begin{array}{l}0.021^{* * *} \\
(0.00)\end{array}$ & $\begin{array}{l}0.021^{* * *} \\
(0.00)\end{array}$ & $\begin{array}{l}0.020^{* * *} \\
(0.00)\end{array}$ & $\begin{array}{l}0.020^{* * *} \\
(0.00)\end{array}$ \\
\hline CAPX $_{i, t}$ & $\begin{array}{l}-0.072 * * * \\
(0.00)\end{array}$ & $\begin{array}{l}-0.063^{* * *} \\
(0.00)\end{array}$ & $\begin{array}{l}-0.069^{* * *} \\
(0.00)\end{array}$ & $\begin{array}{l}-0.072^{* * *} \\
(0.00)\end{array}$ & $\begin{array}{l}-0.067^{* * *} \\
(0.00)\end{array}$ & $\begin{array}{l}-0.073^{* * *} \\
(0.00)\end{array}$ & $\begin{array}{l}-0.067^{* * *} \\
(0.00)\end{array}$ & $\begin{array}{l}-0.068^{* * *} \\
(0.00)\end{array}$ \\
\hline Constant & $\begin{array}{l}0.002^{* * *} \\
(0.00)\end{array}$ & $\begin{array}{l}0.001 \text { *** } \\
(0.00)\end{array}$ & $\begin{array}{l}0.001^{* * *} \\
(0.00)\end{array}$ & $\begin{array}{l}0.001 * * * \\
(0.00)\end{array}$ & $\begin{array}{l}0.001^{* * *} \\
(0.00)\end{array}$ & $\begin{array}{l}0.002^{* * *} \\
(0.00)\end{array}$ & $\begin{array}{l}0.001^{* * *} \\
(0.00)\end{array}$ & $\begin{array}{l}0.001^{* * * *} \\
(0.00)\end{array}$ \\
\hline Observations & 344,618 & 344,618 & 344,618 & 344,618 & 344,618 & 344,618 & 344,618 & 344,618 \\
\hline R-squared & 0.552 & 0.552 & 0.552 & 0.552 & 0.552 & 0.551 & 0.552 & 0.552 \\
\hline Method & Panel & Panel & Panel & Panel & Panel & Panel & Panel & Panel \\
\hline
\end{tabular}


Panel B of Table 5 reports the 2SLS estimation results of future Tobin's Q on different types of long-term ownership. The sample period is 1995-2013 when the instrumental variable is available. Columns (1)-(8) represent the regressions of Tobin's $Q$ on the long-term ownership of independent investors, grey investors, quasi-indexers, dedicated institutional investors, transient investors value investors and growth investors, respectively. The instrument variables are R1TR2, R2TR1, R2TN and NTR2. The first stage estimation is not displayed for simplicity. The fitted values of long-term ownership are used as substitutes in the second stage regressions (denoted with a leading"). All the independent variables are measured at time t. The missing data in the independent variables are filled with $0 .{ }^{* *},{ }^{* *}$, and $*$ denote statistical significance at $1 \%, 5 \%$, and $10 \%$ levels, respectively. Industry (2-digit SIC number) and quarter fixed effects are in all the regressions. The standard errors are clustered at the firm level. Detailed definitions of variables are in Appendix A.

\begin{tabular}{|c|c|c|c|c|c|c|c|c|}
\hline VARIABLES & $\begin{array}{l}(1) \\
\mathrm{TBQ}_{\mathrm{i}, \mathrm{t}+1, \mathrm{t}+4}\end{array}$ & $\begin{array}{l}(2) \\
\mathrm{TBQ}_{\mathrm{i}, \mathrm{t}+1, \mathrm{t}+4}\end{array}$ & $\begin{array}{l}\text { (3) } \\
\mathrm{TBQ}_{\mathrm{i}, \mathrm{t}+1, \mathrm{t}+4}\end{array}$ & $\begin{array}{l}(4) \\
\mathrm{TBQ}_{\mathrm{i}, \mathrm{t}+1, \mathrm{t}+4}\end{array}$ & $\begin{array}{l}(5) \\
\mathrm{TBQ}_{\mathrm{i}, \mathrm{t}+1, \mathrm{t}+4}\end{array}$ & $\begin{array}{l}(6) \\
\mathrm{TBQ}_{\mathrm{i}, \mathrm{t}+1, \mathrm{t}+4}\end{array}$ & $\begin{array}{l}(7) \\
\mathrm{TBQ}_{\mathrm{i}, \mathrm{t}+1, \mathrm{t}+4}\end{array}$ & $\begin{array}{l}(8) \\
\mathrm{TBQ}_{\mathrm{i}, \mathrm{t}+1, \mathrm{t}+4}\end{array}$ \\
\hline IVL3IND $_{i, t}$ & $\begin{array}{l}1.724 * * * \\
(0.00)\end{array}$ & & & & & & & \\
\hline IVL3GRY $_{\mathrm{i}, \mathrm{t}}$ & & $\begin{array}{l}3.129 * * * \\
(0.00)\end{array}$ & & & & & & \\
\hline IVL3QIX $_{i, t}$ & & & $\begin{array}{l}1.463^{* * *} \\
(0.00)\end{array}$ & & & & & \\
\hline IVL3DED $_{i, t}$ & & & & $\begin{array}{l}9.857^{* * * *} \\
(0.00)\end{array}$ & & & & \\
\hline IVL3TRA $_{i, t}$ & & & & & 713 & & & \\
\hline IVL3VAL $_{i, t}$ & & & & & & $\begin{array}{l}4.366^{* * *} \\
(0.00)\end{array}$ & & \\
\hline IVL3GRO $_{i, t}$ & & & & & & & $\begin{array}{l}4.789 * * * \\
(0.00)\end{array}$ & \\
\hline IVL3GI $_{\mathrm{i}, \mathrm{t}}$ & & & & & & & & $\begin{array}{l}2.068^{* * *} \\
(0.00)\end{array}$ \\
\hline $\mathrm{TBQ}_{\mathrm{i}, \mathrm{t}}$ & $\begin{array}{l}0.807 * * * \\
(0.00)\end{array}$ & $\begin{array}{l}0.804^{* * *} \\
(0.00)\end{array}$ & $\begin{array}{l}0.807 * * * \\
(0.00)\end{array}$ & $\begin{array}{l}0.812^{* * *} \\
(0.00)\end{array}$ & $\begin{array}{l}0.797 * * * \\
(0.00)\end{array}$ & $\begin{array}{l}0.829 * * * \\
(0.00)\end{array}$ & $\begin{array}{l}0.787^{* * *} \\
(0.00)\end{array}$ & $\begin{array}{l}0.803^{* * *} \\
(0.00)\end{array}$ \\
\hline $\mathrm{LOGMV}_{\mathrm{i}, \mathrm{t}}$ & $\begin{array}{l}-0.049^{* * *} \\
(0.00)\end{array}$ & $\begin{array}{l}-0.061^{* * * *} \\
(0.00)\end{array}$ & $\begin{array}{l}-0.051 * * * \\
(0.00)\end{array}$ & $\begin{array}{l}-0.060^{* * *} \\
(0.00)\end{array}$ & $\begin{array}{l}-0.052^{* * *} \\
(0.00)\end{array}$ & $\begin{array}{l}-0.046^{* * *} \\
(0.00)\end{array}$ & $\begin{array}{l}-0.045^{* * *} \\
(0.00)\end{array}$ & $\begin{array}{l}-0.058^{* * *} \\
(0.00)\end{array}$ \\
\hline $\mathrm{DTA}_{\mathrm{i}, \mathrm{t}}$ & $\begin{array}{l}-0.063^{* * *} \\
(0.00)\end{array}$ & $\begin{array}{l}-0.072^{* * *} \\
(0.00)\end{array}$ & $\begin{array}{l}-0.055^{* * *} \\
(0.00)\end{array}$ & $\begin{array}{l}-0.107 * * * \\
(0.00)\end{array}$ & $\begin{array}{l}-0.088^{* * *} \\
(0.00)\end{array}$ & $\begin{array}{l}-0.064^{* * *} \\
(0.00)\end{array}$ & $\begin{array}{l}-0.059 * * * \\
(0.00)\end{array}$ & $\begin{array}{l}-0.067^{* * *} \\
(0.00)\end{array}$ \\
\hline $\mathrm{AGE}_{\mathrm{i}, \mathrm{t}}$ & $\begin{array}{l}-0.005^{* * *} \\
(0.00)\end{array}$ & $\begin{array}{l}-0.006^{* * *} \\
(0.00)\end{array}$ & $\begin{array}{l}-0.006^{* * *} \\
(0.00)\end{array}$ & $\begin{array}{l}-0.006 * * * \\
(0.00)\end{array}$ & $\begin{array}{l}-0.004^{* * * *} \\
(0.00)\end{array}$ & $\begin{array}{l}-0.008^{* * *} \\
(0.00)\end{array}$ & $\begin{array}{l}-0.002^{* * * *} \\
(0.00)\end{array}$ & $\begin{array}{l}-0.006^{* * *} \\
(0.00)\end{array}$ \\
\hline $\mathrm{TOV}_{\mathrm{i}, \mathrm{t}}$ & $\begin{array}{l}-0.356^{* * *} \\
(0.00)\end{array}$ & $\begin{array}{l}-0.415^{* * *} \\
(0.00)\end{array}$ & $\begin{array}{l}-0.414^{* * *} \\
(0.00)\end{array}$ & $\begin{array}{l}0.015 \\
(0.66)\end{array}$ & $\begin{array}{l}-0.461 \text { *** } \\
(0.00)\end{array}$ & $\begin{array}{l}-0.346^{* * *} \\
(0.00)\end{array}$ & $\begin{array}{l}-0.302^{* * *} \\
(0.00)\end{array}$ & $\begin{array}{l}-0.420^{* * *} \\
(0.00)\end{array}$ \\
\hline $\mathrm{CAPX}_{i, t}$ & $\begin{array}{l}-0.056 \\
(0.28)\end{array}$ & $\begin{array}{l}-0.041 \\
(0.43)\end{array}$ & $\begin{array}{l}-0.063 \\
(0.23)\end{array}$ & $\begin{array}{l}-0.003 \\
(0.95)\end{array}$ & $\begin{array}{l}-0.025 \\
(0.63)\end{array}$ & $\begin{array}{l}-0.023 \\
(0.67)\end{array}$ & $\begin{array}{l}-0.046 \\
(0.38)\end{array}$ & $\begin{array}{l}-0.071 \\
(0.17)\end{array}$ \\
\hline Constant & $\begin{array}{l}1.805^{* * *} \\
(0.00)\end{array}$ & $\begin{array}{l}2.054^{* * *} \\
(0.00)\end{array}$ & $\begin{array}{l}1.872^{* * *} \\
(0.00)\end{array}$ & $\begin{array}{l}1.807^{* * *} \\
(0.00)\end{array}$ & $\begin{array}{l}1.925^{* * *} \\
(0.00)\end{array}$ & $\begin{array}{l}1.841^{* * *} \\
(0.00)\end{array}$ & $\begin{array}{l}1.766^{* * *} \\
(0.00)\end{array}$ & $\begin{array}{l}1.944^{* * *} \\
(0.00)\end{array}$ \\
\hline Observations & 321,106 & 321,106 & 321,106 & 321,106 & 321,106 & 321,106 & 321,106 & 321,106 \\
\hline R-squared & 0.731 & 0.731 & 0.731 & 0.731 & 0.731 & 0.731 & 0.731 & 0.731 \\
\hline Method & Panel & Panel & Panel & Panel & Panel & Panel & Panel & Panel \\
\hline
\end{tabular}


Panel C of Table 5 reports the 2SLS estimations results of the future Earning Yield on different types of long-term ownership. The sample period is 1995-2013 when the instrumental variable is available. Columns (1)-(8) represent the regressions of Earning Yield on the long-term ownership of independent investors, grey investors, quasi-indexers, dedicated institutional investors, transient investors value investors and growth investors, respectively The instrument variables are R1TR2, R2TR1, R2TN and NTR2. The first stage estimation is not displayed for simplicity. The fitted values of long-term ownerships are used as substitutes in the second stage regressions (denoted with a leading"). All the independent variables are measured at time t. The missing data in he independent variables are filled with $0 .{ }^{* *},{ }^{* *}$, and $*$ denote statistical significance at $1 \%, 5 \%$, and $10 \%$ levels, respectively. Industry (2-digit

\begin{tabular}{|c|c|c|c|c|c|c|c|c|}
\hline & $\begin{array}{l}(1) \\
E Y_{i, t+1, t+4}\end{array}$ & $\begin{array}{l}(2) \\
E Y_{i, t+1, t+4}\end{array}$ & $\begin{array}{l}\text { (3) } \\
E Y_{i, t+1, t+4}\end{array}$ & $\begin{array}{l}\text { (4) } \\
E Y_{i, t+1, t+4}\end{array}$ & $\begin{array}{l}\text { (5) } \\
E Y_{i, t+1, t+4}\end{array}$ & $\begin{array}{l}(6) \\
E Y_{i, t, t+4}\end{array}$ & $\begin{array}{l}(7) \\
E Y_{i, t+1, t+4}\end{array}$ & $\begin{array}{l}\text { (8) } \\
E Y_{i, t+1, t+4}\end{array}$ \\
\hline IVL3IND $_{\mathrm{i}, \mathrm{t}}$ & $\begin{array}{l}0.012 \\
(0.12)\end{array}$ & & & & & & & \\
\hline IVL3GRY $_{i, t}$ & & $\begin{array}{l}0.049 * * * \\
(0.00)\end{array}$ & & & & & & \\
\hline IVL3QIX $_{i, t}$ & & & $\begin{array}{l}0.017 * * \\
(0.02)\end{array}$ & & & & & \\
\hline IVL3DED $_{i, t}$ & & & & $\begin{array}{l}-0.034 \\
(0.48)\end{array}$ & & & & \\
\hline IVL3TRA $_{i, t}$ & & & & & $(0.0$ & & & \\
\hline IVL3VAL $_{i, t}$ & & & & & & $\begin{array}{l}0.035^{*} \\
(0.08)\end{array}$ & & \\
\hline IVL3GRO $_{\mathrm{i}, \mathrm{t}}$ & & & & & & & $\begin{array}{l}0.057 * * \\
(0.02)\end{array}$ & \\
\hline IVL3GI ${ }_{i, t}$ & & & & & & & & $\begin{array}{l}0.021 * * \\
(0.03)\end{array}$ \\
\hline $\mathrm{EY}_{\mathrm{i}, \mathrm{t}}$ & $\begin{array}{l}0.399 * * * \\
(0.00)\end{array}$ & $\begin{array}{l}0.401 * * * \\
(0.00)\end{array}$ & $\begin{array}{l}0.400^{* * *} \\
(0.00)\end{array}$ & $\begin{array}{l}0.399 * * * \\
(0.00)\end{array}$ & $\begin{array}{l}0.399 * * * \\
(0.00)\end{array}$ & $\begin{array}{l}0.399 * * * \\
(0.00)\end{array}$ & $\begin{array}{l}0.400 * * * \\
(0.00)\end{array}$ & $\begin{array}{l}0.400^{* * *} \\
(0.00)\end{array}$ \\
\hline LOGMV $_{i, t}$ & $\begin{array}{l}0.004 * * * \\
(0.00)\end{array}$ & $\begin{array}{l}0.003^{* * *} \\
(0.00)\end{array}$ & $\begin{array}{l}0.004 * * * \\
(0.00)\end{array}$ & $\begin{array}{l}0.005^{* * *} \\
(0.00)\end{array}$ & $\begin{array}{l}0.004 * * * \\
(0.00)\end{array}$ & $\begin{array}{l}0.004^{* * *} \\
(0.00)\end{array}$ & $\begin{array}{l}0.004 * * * \\
(0.00)\end{array}$ & $\begin{array}{l}0.004 * * * \\
(0.00)\end{array}$ \\
\hline DTA $_{i, t}$ & $\begin{array}{l}-0.015^{* * *} \\
(0.00)\end{array}$ & $\begin{array}{l}-0.015^{* * *} \\
(0.00)\end{array}$ & $\begin{array}{l}-0.015^{* * *} \\
(0.00)\end{array}$ & $\begin{array}{l}-0.014^{* * *} \\
(0.00)\end{array}$ & $\begin{array}{l}-0.015^{* * *} \\
(0.00)\end{array}$ & $\begin{array}{l}-0.015^{* * *} \\
(0.00)\end{array}$ & $\begin{array}{l}-0.015^{* * *} \\
(0.00)\end{array}$ & $\begin{array}{l}-0.015^{* * *} \\
(0.00)\end{array}$ \\
\hline $\mathrm{AGE}_{\mathrm{i}, \mathrm{t}}$ & $\begin{array}{l}0.000^{* * *} \\
(0.00)\end{array}$ & $\begin{array}{l}0.000^{* *} \\
(0.01)\end{array}$ & $\begin{array}{l}0.000^{* * *} \\
(0.00)\end{array}$ & $\begin{array}{l}0.000^{* * *} \\
(0.00)\end{array}$ & $\begin{array}{l}0.000^{* * *} \\
(0.00)\end{array}$ & $\begin{array}{l}0.000^{* * *} \\
(0.00)\end{array}$ & $\begin{array}{l}0.000^{* * *} \\
(0.00)\end{array}$ & $\begin{array}{l}0.000^{* * *} \\
(0.00)\end{array}$ \\
\hline $\operatorname{TOV}_{\mathrm{i}, \mathrm{t}}$ & $\begin{array}{l}-0.034^{* * *} \\
(0.00)\end{array}$ & $\begin{array}{l}-0.035^{* * *} \\
(0.00)\end{array}$ & $\begin{array}{l}-0.034 * * * \\
(0.00)\end{array}$ & $\begin{array}{l}-0.035 * * * \\
(0.00)\end{array}$ & $\begin{array}{l}-0.035^{* * *} \\
(0.00)\end{array}$ & $\begin{array}{l}-0.033^{* * *} \\
(0.00)\end{array}$ & $\begin{array}{l}-0.033 * * * \\
(0.00)\end{array}$ & $\begin{array}{l}-0.034 * * * \\
(0.00)\end{array}$ \\
\hline CAPX $_{i, t}$ & $\begin{array}{l}0.017^{* * *} \\
(0.00)\end{array}$ & $\begin{array}{l}0.019 * * * \\
(0.00)\end{array}$ & $\begin{array}{l}0.018^{* * *} \\
(0.00)\end{array}$ & $\begin{array}{l}0.016^{* * *} \\
(0.00)\end{array}$ & $\begin{array}{l}0.018^{* * *} \\
(0.00)\end{array}$ & $\begin{array}{l}0.018^{* * *} \\
(0.00)\end{array}$ & $\begin{array}{l}0.018^{* * *} \\
(0.00)\end{array}$ & $\begin{array}{l}0.017^{* * *} \\
(0.00)\end{array}$ \\
\hline Constant & $\begin{array}{l}-0.111^{\text {*** }} \\
(0.00)\end{array}$ & $\begin{array}{l}-0.098^{* * *} \\
(0.00)\end{array}$ & $\begin{array}{l}-0.105^{\text {*** }} \\
(0.00)\end{array}$ & $\begin{array}{l}-0.121^{* * *} \\
(0.00)\end{array}$ & $\begin{array}{l}-0.107^{* * *} \\
(0.00)\end{array}$ & $\begin{array}{l}-0.110^{* * *} \\
(0.00)\end{array}$ & $\begin{array}{l}-0.106^{* * *} \\
(0.00)\end{array}$ & $\begin{array}{l}-0.106^{* * *} \\
(0.00)\end{array}$ \\
\hline Observations & 348,949 & 348,949 & 348,949 & 348,949 & 348,949 & 348,949 & 348,949 & 348,949 \\
\hline R-squared & 0.283 & 0.283 & 0.283 & 0.283 & 0.283 & 0.283 & 0.283 & 0.283 \\
\hline Method & Panel & Panel & Panel & Panel & Panel & Panel & Panel & Panel \\
\hline
\end{tabular}

SIC number) and quarter fixed effects are in all the regressions. The standard errors are clustered at the firm level Detailed definitions of variables are in Appendix A. 
Table 6 2SLS, Alternative measures of long-term ownership

Table 6 reports the 2SLS estimation results of firm performance on the alternative measures of long-term ownership. The sample period is 1995-2013 when the instrumental variable is available. The first stage estimation is not displayed for simplicity. The fitted values of LIOP(IVLIOP) and L5(IVL5) are used as substitutes in the second stage regressions. All the independent variables are measured at time $t$. The missing data in the independent variables are filled with $0 . * * *, * *$, and * denote statistical significance at $1 \%, 5 \%$, and $10 \%$ levels, respectively. Industry (2-digit SIC number) and quarter fixed effects are in all the regressions. The standard errors are clustered at the firm level. Detailed definitions of variables are in Appendix A.

\begin{tabular}{|c|c|c|c|c|c|c|}
\hline & $\begin{array}{l}(1) \\
\mathrm{ROA}_{\mathrm{i}, \mathrm{t}+1, \mathrm{t}+4}\end{array}$ & $\begin{array}{l}\text { (2) } \\
\text { TBQ }_{i, t+1, t+4}\end{array}$ & $\begin{array}{l}(3) \\
E Y_{i, t+1, t+4}\end{array}$ & $\begin{array}{l}(4) \\
\mathrm{ROA}_{\mathrm{i}, \mathrm{t}+1, \mathrm{t}+4}\end{array}$ & $\begin{array}{l}\text { (5) } \\
\text { TBQ }_{\mathrm{i}, \mathrm{t}+1, \mathrm{t}+4}\end{array}$ & $\begin{array}{l}(6) \\
E Y_{i, t+1, t+4}\end{array}$ \\
\hline IVLIOP $_{i, t}$ & $\begin{array}{l}0.055^{* * *} \\
(0.00)\end{array}$ & $\begin{array}{l}3.463^{* * *} \\
(0.00)\end{array}$ & $\begin{array}{l}-0.028 \\
(0.37)\end{array}$ & & & \\
\hline IVL5 $5_{i, t}$ & & & & $(0.00)$ & $\begin{array}{l}1.499^{* * *} \\
(0.00)\end{array}$ & $\begin{array}{l}0.023^{* * *} \\
(0.00)\end{array}$ \\
\hline $\mathrm{ROA}_{\mathrm{i}, \mathrm{t}}$ & $\begin{array}{l}0.627^{* * *} \\
(0.00)\end{array}$ & & & $0.630^{* * *}$ & & \\
\hline $\mathrm{TBQ}_{\mathrm{i}, \mathrm{t}}$ & & $\begin{array}{l}0.776^{* * *} \\
(0.00)\end{array}$ & & & $\begin{array}{l}0.765^{* * *} \\
(0.00)\end{array}$ & \\
\hline $\mathrm{EY}_{\mathrm{i}, \mathrm{t}}$ & & & $\begin{array}{l}0.508^{* * *} \\
(0.00)\end{array}$ & & & $\begin{array}{l}0.509 * * * \\
(0.00)\end{array}$ \\
\hline LOGMV $_{i, t}$ & $\begin{array}{l}0.001 \text { *** } \\
(0.00)\end{array}$ & $\begin{array}{l}-0.061^{* * *} \\
(0.00)\end{array}$ & $\begin{array}{l}0.005^{* * *} \\
(0.00)\end{array}$ & $\begin{array}{l}0.001 \text { *** } \\
(0.00)\end{array}$ & $\begin{array}{l}-0.047 * * * \\
(0.00)\end{array}$ & $\begin{array}{l}0.004^{* * *} \\
(0.00)\end{array}$ \\
\hline DTA $_{i, t}$ & $\begin{array}{l}0.001 \\
(0.15)\end{array}$ & $\begin{array}{l}-0.093 * * * \\
(0.00)\end{array}$ & $\begin{array}{l}-0.013^{* * *} \\
(0.00)\end{array}$ & $\begin{array}{l}0.001 * \\
(0.07)\end{array}$ & $\begin{array}{l}-0.084^{* * *} \\
(0.00)\end{array}$ & $\begin{array}{l}-0.013^{* * *} \\
(0.00)\end{array}$ \\
\hline $\mathrm{AGE}_{\mathrm{i}, \mathrm{t}}$ & $\begin{array}{l}0.000^{* *} \\
(0.04)\end{array}$ & $\begin{array}{l}-0.007 * * * \\
(0.00)\end{array}$ & $\begin{array}{l}0.000^{* * *} \\
(0.00)\end{array}$ & $\begin{array}{l}-0.000 \\
(0.70)\end{array}$ & $\begin{array}{l}-0.009^{* * *} \\
(0.00)\end{array}$ & $\begin{array}{l}0.000 \\
(0.30)\end{array}$ \\
\hline $\operatorname{TOV}_{\mathrm{i}, \mathrm{t}}$ & $\begin{array}{l}-0.019 \text { *** } \\
(0.00)\end{array}$ & $\begin{array}{l}-0.345^{* * *} \\
(0.00)\end{array}$ & $\begin{array}{l}-0.030^{* * *} \\
(0.00)\end{array}$ & $\begin{array}{l}-0.019^{* * *} \\
(0.00)\end{array}$ & $\begin{array}{l}-0.315^{* * *} \\
(0.00)\end{array}$ & $\begin{array}{l}-0.031^{\text {*** }} \\
(0.00)\end{array}$ \\
\hline CAPX $_{i, t}$ & $\begin{array}{l}0.019 * * * \\
(0.00)\end{array}$ & $\begin{array}{l}-0.030 \\
(0.63)\end{array}$ & $\begin{array}{l}0.013^{* * *} \\
(0.00)\end{array}$ & $\begin{array}{l}0.020^{* * *} \\
(0.00)\end{array}$ & $\begin{array}{l}-0.006 \\
(0.91)\end{array}$ & $\begin{array}{l}0.016^{* * *} \\
(0.00)\end{array}$ \\
\hline Constant & $\begin{array}{l}-0.034^{* * *} \\
(0.00)\end{array}$ & $\begin{array}{l}1.454^{* * *} \\
(0.00)\end{array}$ & $\begin{array}{l}-0.094^{* * *} \\
(0.00)\end{array}$ & $\begin{array}{l}-0.028^{* * *} \\
(0.00)\end{array}$ & $\begin{array}{l}1.451^{* * *} \\
(0.00)\end{array}$ & $\begin{array}{l}-0.069 * * * \\
(0.00)\end{array}$ \\
\hline Industry FE & 1 & Y & $\mathrm{Y}$ & Y & Y & $\mathrm{Y}$ \\
\hline Time FE & Y & $\mathrm{Y}$ & $\mathrm{Y}$ & $\mathrm{Y}$ & $\mathrm{Y}$ & $\mathrm{Y}$ \\
\hline Observations & 344,618 & 321,106 & 348,949 & 344,618 & 321,106 & 348,949 \\
\hline R-squared & 0.551 & 0.731 & 0.283 & 0.552 & 0.731 & 0.283 \\
\hline
\end{tabular}


Table 7 Short-term ownership and firm performance

Table 7 reports the 2SLS estimations results of firm performance on short-term ownership. The sample period is 1995-2013 when the instrumental variable is available. The first stage estimation is not displayed for simplicity. The fitted values of S1(IVS1) and SIOP(IVSIOP) are used as substitutes in the second stage regressions. All the independent variables are measured at time t. The missing data in the independent variables are filled with $0 . * * *, * *$, and $*$ denote statistical significance at $1 \%, 5 \%$ and $10 \%$ levels, respectively. Industry ( 2 digit SIC number) and quarter fixed

effects are in all the regressions. The standard errors are clustered at the firm level. Detailed definitions of variables are in Appendix A.

\begin{tabular}{|c|c|c|c|c|c|c|c|c|c|}
\hline & $\begin{array}{l}(1) \\
\mathrm{ROA}_{\mathrm{i}, \mathrm{t}+1, \mathrm{t}+4}\end{array}$ & $\begin{array}{l}(2) \\
\mathrm{ROA}_{\mathrm{i}, \mathrm{t}+1, \mathrm{t}+4}\end{array}$ & $\begin{array}{l}\text { (3) } \\
\mathrm{ROA}_{\mathrm{i}, \mathrm{t}+1, \mathrm{t}+4}\end{array}$ & $\begin{array}{l}(4) \\
\text { TBQ }_{i, t, t+4}\end{array}$ & $\begin{array}{l}(5) \\
\text { TBQ }_{i, t+1, t+4}\end{array}$ & $\begin{array}{l}(6) \\
\text { TBQ }_{\mathrm{i}, \mathrm{t}+1, \mathrm{t}+4}\end{array}$ & $\begin{array}{l}(7) \\
E Y_{i, t+1, t+4}\end{array}$ & $\begin{array}{l}(8) \\
\mathrm{EY}_{\mathrm{i}, \mathrm{t}+1, \mathrm{t}+4}\end{array}$ & $\begin{array}{l}(9) \\
E Y_{i, t+1, t+4}\end{array}$ \\
\hline IVS1 $_{i, t}$ & $\begin{array}{l}-0.066^{* * *} \\
(0.00)\end{array}$ & & & $\begin{array}{l}-3.954 * * * \\
(0.00)\end{array}$ & & & $-0.036^{*}$ & & \\
\hline IVS $2_{i, t}$ & & $\begin{array}{l}-0.029 * * * \\
(0.00)\end{array}$ & & & $\begin{array}{l}-1.717^{* * *} \\
(0.00)\end{array}$ & & & $\begin{array}{l}-0.019 * * \\
(0.03)\end{array}$ & \\
\hline $\operatorname{IVSIOP}_{\mathrm{i}, \mathrm{t}}$ & & & $\begin{array}{l}-0.020^{* *} \\
(0.01)\end{array}$ & & & & & & $\begin{array}{l}-0.004 \\
(0.77)\end{array}$ \\
\hline $\mathrm{ROA}_{i, \mathrm{t}}$ & $\begin{array}{l}0.624 * * * \\
(0.00)\end{array}$ & $\begin{array}{l}0.623^{* * *} \\
(0.00)\end{array}$ & $\begin{array}{l}0.622^{* * *} \\
(0.00)\end{array}$ & & & & & & \\
\hline $\mathrm{TBQ}_{\mathrm{i}, \mathrm{t}}$ & & & & $\begin{array}{l}0.783^{* * *} \\
(0.00)\end{array}$ & $\begin{array}{l}0.780^{* *} \\
(0.00)\end{array}$ & $\begin{array}{l}0.782^{* * *} \\
(0.00)\end{array}$ & & & \\
\hline $\mathrm{EY}_{\mathrm{i}, \mathrm{t}}$ & & & & & & & $\begin{array}{l}0.401^{* * *} \\
(0.00)\end{array}$ & $\begin{array}{l}0.400^{* * *} \\
(0.00)\end{array}$ & $\begin{array}{l}0.399 * * * \\
(0.00)\end{array}$ \\
\hline LOGMV $_{i, t}$ & $\begin{array}{l}0.003^{* * *} \\
(0.00)\end{array}$ & $\begin{array}{l}0.003^{* * *} \\
(0.00)\end{array}$ & $\begin{array}{l}0.003^{* * *} \\
(0.00)\end{array}$ & $\begin{array}{l}0.024 * * * \\
(0.00)\end{array}$ & $\begin{array}{l}0.028 * * * \\
(0.00)\end{array}$ & $\begin{array}{l}0.058^{* * *} \\
(0.00)\end{array}$ & $\begin{array}{l}0.004 * * * \\
(0.00)\end{array}$ & $\begin{array}{l}0.004 * * * \\
(0.00)\end{array}$ & $\begin{array}{l}0.004^{* * *} \\
(0.00)\end{array}$ \\
\hline DTA $_{i, t}$ & $\begin{array}{l}0.001^{* *} \\
(0.01)\end{array}$ & $\begin{array}{l}0.002^{* * *} \\
(0.01)\end{array}$ & $\begin{array}{l}0.002 * * * \\
(0.00)\end{array}$ & $\begin{array}{l}-0.058^{* * *} \\
(0.00)\end{array}$ & $\begin{array}{l}-0.050^{* * *} \\
(0.00)\end{array}$ & $\begin{array}{l}-0.030^{* *} \\
(0.02)\end{array}$ & $\begin{array}{l}-0.015^{* * *} \\
(0.00)\end{array}$ & $\begin{array}{l}-0.014^{* * *} \\
(0.00)\end{array}$ & $\begin{array}{l}-0.015^{* * *} \\
(0.00)\end{array}$ \\
\hline $\mathrm{AGE}_{i, \mathrm{t}}$ & $\begin{array}{l}0.000^{* * *} \\
(0.00)\end{array}$ & $\begin{array}{l}0.000^{* * *} \\
(0.00)\end{array}$ & $\begin{array}{l}0.000^{* * * *} \\
(0.00)\end{array}$ & $\begin{array}{l}-0.003^{* * *} \\
(0.00)\end{array}$ & $\begin{array}{l}-0.004^{* * *} \\
(0.00)\end{array}$ & $\begin{array}{l}-0.003^{* * *} \\
(0.00)\end{array}$ & $\begin{array}{l}0.000^{* * *} \\
(0.00)\end{array}$ & $\begin{array}{l}0.000^{* * * *} \\
(0.00)\end{array}$ & $\begin{array}{l}0.000^{* * *} \\
(0.00)\end{array}$ \\
\hline $\operatorname{TOV}_{i, t}$ & $\begin{array}{l}-0.005^{* *} \\
(0.04)\end{array}$ & $\begin{array}{l}-0.008^{* * *} \\
(0.00)\end{array}$ & $\begin{array}{l}-0.012^{* * *} \\
(0.00)\end{array}$ & $\begin{array}{l}0.361^{* * *} \\
(0.00)\end{array}$ & $\begin{array}{l}0.152^{* * *} \\
(0.00)\end{array}$ & $\begin{array}{l}0.150^{* * *} \\
(0.00)\end{array}$ & $\begin{array}{l}-0.027^{* * *} \\
(0.00)\end{array}$ & $\begin{array}{l}-0.028^{* * *} \\
(0.00)\end{array}$ & $\begin{array}{l}-0.033^{* * *} \\
(0.00)\end{array}$ \\
\hline CAPX $_{i, t}$ & $\begin{array}{l}0.019 \text { *** } \\
(0.00)\end{array}$ & $\begin{array}{l}0.019 * * * \\
(0.00)\end{array}$ & $\begin{array}{l}0.018^{* * * *} \\
(0.00)\end{array}$ & $\begin{array}{l}-0.112^{* *} \\
(0.03)\end{array}$ & $\begin{array}{l}-0.115^{* *} \\
(0.03)\end{array}$ & $\begin{array}{l}-0.164 * * * \\
(0.00)\end{array}$ & $\begin{array}{l}0.017^{* * *} \\
(0.00)\end{array}$ & $\begin{array}{l}0.017 * * * \\
(0.00)\end{array}$ & $\begin{array}{l}0.016^{* * *} \\
(0.00)\end{array}$ \\
\hline Constant & $\begin{array}{l}-0.084 * * * \\
(0.00)\end{array}$ & $\begin{array}{l}-0.089 \text { *** } \\
(0.00)\end{array}$ & $\begin{array}{l}-0.094 * * * \\
(0.00)\end{array}$ & $\begin{array}{l}0.820 \\
(0.14)\end{array}$ & $\begin{array}{l}0.558 \\
(0.31)\end{array}$ & $\begin{array}{l}-0.046 \\
(0.94)\end{array}$ & $\begin{array}{l}-0.117^{* * *} \\
(0.00)\end{array}$ & $\begin{array}{l}-0.120^{* * *} \\
(0.00)\end{array}$ & $\begin{array}{l}-0.119^{\text {*** }} \\
(0.00)\end{array}$ \\
\hline Industry FE & Y & Y & $\mathrm{Y}$ & Y & Y & Y & Y & Y & Y \\
\hline Time FE & $\mathrm{Y}$ & $\mathrm{Y}$ & $\mathrm{Y}$ & $\mathrm{Y}$ & $\mathrm{Y}$ & $\mathrm{Y}$ & $\mathrm{Y}$ & $\mathrm{Y}$ & $\mathrm{Y}$ \\
\hline Observations & 344,618 & 344,618 & 344,618 & 321,106 & 321,106 & 321,106 & 348,949 & 348,949 & 348,949 \\
\hline R-squared & 0.552 & 0.552 & 0.551 & 0.731 & 0.731 & 0.731 & 0.283 & 0.283 & 0.283 \\
\hline
\end{tabular}


Appendix A

\begin{tabular}{|c|c|c|}
\hline Variables: & Definition: & Source: \\
\hline \multicolumn{3}{|c|}{ Dependent Variables: } \\
\hline $\mathrm{ROA}_{\mathrm{i}, \mathrm{t}+1, \mathrm{t}+4}$ & $\begin{array}{l}\text { Average quarterly ROA from } t \text { to } t+4 \text { quarter. ROA is defined as net income (NIQ)/total } \\
\text { asset(ATQ). }\end{array}$ & COMPUSTAT \\
\hline $\mathrm{TBQ}_{\mathrm{i}, \mathrm{t}+1, \mathrm{t}+4}$ & $\begin{array}{l}\text { Average Tobin's } Q \text { from t to t+4 quarter. Tobin's } Q \text { is defined as the market value of equity } \\
\text { (CSHOQ*PRCCQ) + book value of debt (DLTTQ+DLCQ)) standardized by total assets (ATQ). }\end{array}$ & COMPUSTAT \\
\hline$E Y_{i, t+1, t+4}$ & Average earnings per share (EPSFXQ) from $t$ to $t+4$ quarter standardized by stock price at time $t$. & COMPUSTAT \\
\hline & \multicolumn{2}{|c|}{$\begin{array}{l}\text { Industry adjustment is applied to all dependent variables. We deduct the quarterly median value of industry ( } 2 \text { digit SIC code) } \\
\text { performance from the firm performance variables to make such an adjustment. }\end{array}$} \\
\hline \multicolumn{3}{|c|}{ Ownership Variables: } \\
\hline L3 & $\begin{array}{l}\text { Ownership of investors who hold shares of the firm for more than three years, aggregated at the firm } \\
\text { level. If an investor sold out all the holdings but returned within one year, the holding period is carried } \\
\text { forward from the previous holding. }\end{array}$ & $\begin{array}{l}\text { Thomson Financial Institutional } \\
\text { Ownership }\end{array}$ \\
\hline L5 & $\begin{array}{l}\text { Ownership of investors who hold shares of the firm for more than five years, aggregated at the firm } \\
\text { level. If an investor sold out all the holdings but returned within one year, the holding period is carried } \\
\text { forward from the previous holding. }\end{array}$ & $\begin{array}{l}\text { Thomson Financial Institutional } \\
\text { Ownership }\end{array}$ \\
\hline LIOP & $\begin{array}{l}\text { Ownership of investors who are classified as long-term investors based on Yan and Zhang (2009), } \\
\text { aggregated at the firm level. The classification is based on the "churn ratio" while each quarter } \\
\text { investors whose churn ratio is in the lowest } 1 / 3 \text { (slow turnover) long-term investors. See Yan and } \\
\text { Zhang (2009) for details. }\end{array}$ & $\begin{array}{l}\text { Thomson Financial Institutional } \\
\text { Ownership }\end{array}$ \\
\hline S1 & $\begin{array}{l}\text { Ownership of investors whose entire holding period from enter to exit is less than one year and do } \\
\text { not return within the next one year, aggregated at the firm level. }\end{array}$ & \\
\hline S2 & $\begin{array}{l}\text { Ownership of investors whose entire holding period from enter to exit is less than two years and do } \\
\text { not return within the next one year, aggregated at the firm level. }\end{array}$ & \\
\hline \multirow[t]{2}{*}{ SIOP } & $\begin{array}{l}\text { Ownership of investors who are classified as long-term investors based on Yan and Zhang (2009), } \\
\text { aggregated at the firm level. The classification is based on the "churn ratio" where each quarter } \\
\text { investors whose churn ratio is in the highest } 1 / 3 \text { (faster turnover) are classified short-term investors. } \\
\text { See Yan and Zhang (2009) for details. }\end{array}$ & $\begin{array}{l}\text { Thomson Financial Institutional } \\
\text { Ownership }\end{array}$ \\
\hline & Classification by Bushee and Goodman (2007) & \\
\hline GROL3 & $\begin{array}{l}\text { Percentage shares of the firm held by "growth investors" who hold the stocks for more than three } \\
\text { years. aggregated at the firm level. If an investor sold out all the holdings but returned within one year, } \\
\text { the holding period is carried forward from the previous holding. Growth investors are defined as } \\
\text { those who prefer higher price to book ratio, higher price to earning ratio and lower dividend yield. }\end{array}$ & $\begin{array}{l}\text { Thomson Financial Institutional } \\
\text { Ownership and Bushee and } \\
\text { Goodman (2007) }\end{array}$ \\
\hline
\end{tabular}


VALL3

DEDL3

INDL3

GRYL3
Percentage shares of the firm held by "value investors" who hold the stocks for more than three years. aggregated at the firm level. If an investor sold out all the holdings but returned within one year, the holding period is carried forward from the previous holding. Value investors are defined as those who prefer lower price to book ratio, lower price to earning ratio and higher dividend yield.

Percentage shares of the firm held by "growth/income investors" who hold the stocks for more than three years. aggregated at the firm level. If an investor sold out all the holdings but returned within one year, the holding period is carried forward from the previous holding. Investors who follow neither growth or value style are classified as growth/income investors.

Percentage shares of the firm held by "dedicate investors" who hold the stocks for more than three years. aggregated at the firm level. If an investor sold out all the holdings but returned within one year, the holding period is carried forward from the previous holding Dedicate investors are defined as investors with low turnover and concentrated portfolios.

Percentage shares of the firm held by "quasi-indexers" who hold the stocks for more than three years. aggregated at the firm level. If an investor sold out all the holdings but returned within one year, the holding period is carried forward from the previous holding. Quasi-indexers are defined as investors with low portfolio turnover and diversified portfolio.

Percentage shares of the firm held by "growth/income investors" who hold the stocks for more than three years. aggregated at the firm level. If an investor sold out all the holdings but returned within one year, the holding period is carried forward from the previous holding. Transient investors are those who have high portfolio turnover and highly diversified portfolio.

Percentage shares of the firm held by "independent investors" who hold the stocks for more than three years, aggregated at the firm level. If an investor sold out all the holdings but returned within one year, the holding period is carried forward from the previous holding. Independent investors are those who have less business relationship with the underlying firm, including independent investment advisors, investment companies and public pension funds.

Percentage shares of the firm held by "grey investors" who hold the stocks for more than three years. aggregated at the firm level. If an investor sold out all the holdings but returned within one year, the holding period is carried forward from the previous holding. Grey investors are those who have more business relationship with the underlying firm, including banks, insurance companies, corporate pension funds, public pension funds university and foundation endowments and other investors.

All Bushee's classifications are from Bushee's website:

http://acct.wharton.upenn.edu/faculty/bushee/IIclass.html.
Thomson Financial Institutional

Ownership \& Bushee and

Goodman (2007)

Thomson Financial Institutional Ownership \& Bushee and Goodman (2007)

Thomson Financial Institutional Ownership \& Bushee and

Goodman (2007)

Thomson Financial Institutional Ownership \& Bushee and Goodman (2007)

Thomson Financial Institutional Ownership \& Bushee and Goodman (2007)

Thomson Financial Institutional Ownership \& Bushee and Goodman (2007)

Thomson Financial Institutional Ownership \& Bushee and Goodman (2007)

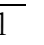

(n)




\begin{tabular}{|c|c|c|}
\hline \multicolumn{3}{|c|}{ Control Variables: } \\
\hline LOGMV & $\begin{array}{l}\text { Log of firm market capitalization. Market capitalization calculated as price (PRC)*total shares } \\
\text { outstanding (SHROUT). }\end{array}$ & CRSP \\
\hline DTA & Book leverage, calculated as total debt (DLTTQ+DLCQ) to total assets (ATQ). & COMPUSTAT \\
\hline AGE & Number of years since the stock first emerged in the CRSP database. & CRSP \\
\hline TOV & $\begin{array}{l}\text { Quarterly turnover, calculated as quarterly trading volume (VOL) divided by shares outs } \\
\text { (SHROUT). }\end{array}$ & CRSP \\
\hline CAPX & Capital expenditure ratio. CAPX is defined as CAPX/ATQ. & COMPUST \\
\hline \multicolumn{3}{|c|}{ Instrument Variables: } \\
\hline R1TR2 & $\begin{array}{l}\text { Dummy variable. Takes the value of one at the quarterly following a firm switch from Russell } 1000 \text { to } \\
\text { Russell } 2000 \text { index. Zero otherwise. }\end{array}$ & Bloomberg \\
\hline R2TR1 & $\begin{array}{l}\text { Dummy variable. Takes the value of one at the quarterly following a firm switch from Russell } 2000 \text { to } \\
\text { Russell } 1000 \text { index. Zero otherwise. }\end{array}$ & Bloomberg \\
\hline R1TR2 & $\begin{array}{l}\text { Dummy variable. Takes the value of one at the quarterly following a firm dropping out from Russell } \\
2000 \text { due to a decrease in market value. Zero otherwise. }\end{array}$ & Bloomberg \\
\hline R1TR2 & $\begin{array}{l}\text { Dummy variable. Takes the value of one at the quarterly following a firm inclusion first time in } \\
\text { Russell } 2000 \text { due to a market value increase. Zero otherwise. }\end{array}$ & Bloomberg \\
\hline
\end{tabular}




\section{Appendix B}

Table B1 Baseline regression using unadjusted performance variable

Table B1 reports the panel regression coefficients of the baseline regression with performance measures that have not been adjusted by industry. The dependent variables are ROA, Tobin's $\mathrm{Q}$ and $\mathrm{EY}$, measured as the average from quarter $\mathrm{t}+1$ to $\mathrm{t}+4$. The sample period is 1982-2013. All the independent variables are measured at time $t$. The missing data in the independent variables are filled with 0 . ***, **, and * denote statistical significance at $1 \%, 5 \%$, and $10 \%$ levels, respectively. Industry (2-digit SIC number) and quarter fixed effects are in all the regressions. The standard errors are clustered at the firm level. Detailed definitions of variables are in Appendix A.

\begin{tabular}{|c|c|c|c|}
\hline & $\begin{array}{c}(1) \\
\mathrm{ROA}_{\mathrm{i}, \mathrm{t}+1, \mathrm{t}+4}\end{array}$ & $\begin{array}{c}(2) \\
T B Q_{i, t+1, t+4} \\
\end{array}$ & $\begin{array}{c}(3) \\
E Y_{i, t+1, t+4} \\
\end{array}$ \\
\hline $\mathrm{L} 3_{\mathrm{i}, \mathrm{t}}$ & $\begin{array}{c}0.010^{* * *} \\
(0.00)\end{array}$ & $\begin{array}{c}0.039 * * * \\
(0.00)\end{array}$ & $\begin{array}{c}0.007 * * * \\
(0.00)\end{array}$ \\
\hline $\mathrm{ROA}_{\mathrm{i}, \mathrm{t}}$ & $\begin{array}{c}0.613^{* * *} \\
(0.00)\end{array}$ & & \\
\hline $\mathrm{TBQ}_{\mathrm{i}, \mathrm{t}}$ & & $\begin{array}{c}0.757 * * * \\
(0.00)\end{array}$ & \\
\hline$E Y_{i, t}$ & & & $0.500 * * *$ \\
\hline LOGMV $_{i, t}$ & $\begin{array}{c}0.002^{* * *} \\
(0.00)\end{array}$ & $\begin{array}{c}0.011 * * * \\
(0.00)\end{array}$ & $\begin{array}{c}0.004^{* * *} \\
(0.00)\end{array}$ \\
\hline DTA $_{i, t}$ & $\begin{array}{c}-0.000 \\
(0.31)\end{array}$ & $\begin{array}{c}-0.100^{* * *} \\
(0.00)\end{array}$ & $\begin{array}{c}-0.015^{* * *} \\
(0.00)\end{array}$ \\
\hline $\mathrm{AGE}_{\mathrm{i}, \mathrm{t}}$ & $\begin{array}{c}0.000 * * * \\
(0.00)\end{array}$ & $\begin{array}{c}-0.000^{* * *} \\
(0.00)\end{array}$ & $\begin{array}{c}0.000^{* * *} \\
(0.00)\end{array}$ \\
\hline $\operatorname{TOV}_{\mathrm{i}, \mathrm{t}}$ & $\begin{array}{c}-0.020^{* * *} \\
(0.00)\end{array}$ & $\begin{array}{c}-0.245^{* * *} \\
(0.00)\end{array}$ & $\begin{array}{c}-0.032^{* * *} \\
(0.00)\end{array}$ \\
\hline $\mathrm{CAPX}_{\mathrm{i}, \mathrm{t}}$ & $\begin{array}{c}0.017^{* * *} \\
(0.00)\end{array}$ & $\begin{array}{c}-0.096^{* *} \\
(0.02)\end{array}$ & $\begin{array}{c}0.016^{* * *} \\
(0.00)\end{array}$ \\
\hline Constant & $\begin{array}{c}-0.040^{* * *} \\
(0.00)\end{array}$ & $\begin{array}{c}0.267 * * * \\
(0.00)\end{array}$ & $\begin{array}{c}-0.073^{* * *} \\
(0.00)\end{array}$ \\
\hline $\begin{array}{l}\text { Industry FE } \\
\text { Time FE } \\
\text { Observation } \\
\text { R-squared }\end{array}$ & $\begin{array}{c}\mathrm{Y} \\
\mathrm{Y} \\
549,400 \\
0.569\end{array}$ & $\begin{array}{c}Y \\
Y \\
507,429 \\
0.772\end{array}$ & $\begin{array}{c}\mathrm{Y} \\
\mathrm{Y} \\
550,107 \\
0.373\end{array}$ \\
\hline
\end{tabular}

Robust $\mathrm{p}$-value in parentheses.

*** $\mathrm{p}<0.01,{ }^{* *} \mathrm{p}<0.05,{ }^{*} \mathrm{p}<0.1$ 
Table B2 2L3 rank change over the long term

Table B2 reports the likelihood of the long-term holding ranking in $t+5$ years. All firms are ranked into five different portfolio according to the long-term holdings of institutional investors (L3) at time t. Portfolio 1 represents firms with the least long-term holdings while P5 represents firms with the most long-term holdings. Then for each current portfolio, the probability that the firm ends up in a portfolio with a different rank in $t+5$ years is displayed in the table.

\begin{tabular}{c|rrrrrr}
\hline & \multicolumn{6}{|c}{ Five-year-later rank } \\
\hline \multirow{5}{*}{ Current } & & 1 & 2 & 3 & 4 & 5 \\
& 1 & $58.0 \%$ & $28.3 \%$ & $10.3 \%$ & $2.4 \%$ & $1.1 \%$ \\
rank & 2 & $41.0 \%$ & $28.3 \%$ & $23.6 \%$ & $5.9 \%$ & $1.2 \%$ \\
& 3 & $33.5 \%$ & $12.8 \%$ & $30.9 \%$ & $19.0 \%$ & $3.8 \%$ \\
& 4 & $24.2 \%$ & $4.5 \%$ & $19.2 \%$ & $33.6 \%$ & $18.5 \%$ \\
& 5 & $15.8 \%$ & $1.1 \%$ & $5.8 \%$ & $19.7 \%$ & $57.6 \%$ \\
\hline
\end{tabular}


Table B3 Long-term holding and performance persistence

Table B3 reports the double sort result of firm performance. In each panel, all the firms are sorted into 25 different portfolios by current long-term holdings and current performance. The average future performance from quarter $\mathrm{t}+1$ to $\mathrm{t}+4$ are shown in the table. The performance measures are ROA, Tobin's $\mathrm{Q}$ and EY, respectively. The sample period is $\mathrm{m} 1982-2013 . * * *, * *$, and $*$ denote statistical significance at $1 \%, 5 \%$, and $10 \%$ levels, respectively.

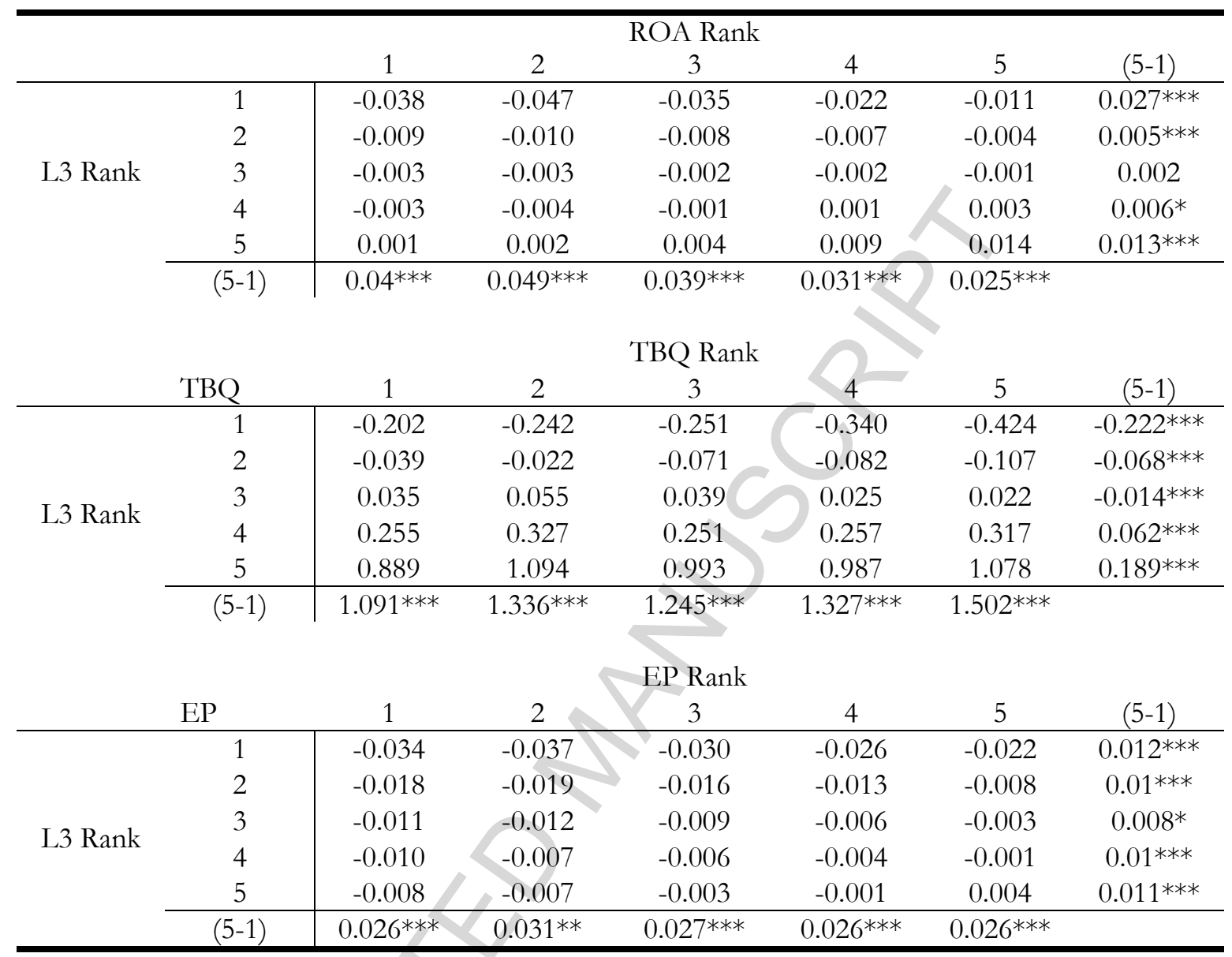


Highlights:

- This paper investigates whether institutional investors that hold shares in a firm for a relatively long time affect firm performance, measured by Return on Assets (ROA), Tobin's Q and Earnings Yield

- We find that long-term ownership of institutional investors has a positive, long-lasting effect on firm performance.

- We further find that the incentive for monitoring firm performance associated with longterm holding is more important than some conventional classifications of investors in improving firm value.

- We also find that a positive link between institutional owners and firm performance does not exist when investors only hold the stock for a short term. 